\title{
NOTES ON AVICENNA'S CONCEPT OF THINGNESS (S'AY'TYYA)*
}

\author{
ROBERT WISNOVSKY
}

In an article published in 1984, Jean Jolivet suggested that the origins of Avicenna's distinction between essence and existence lay not in ancient Greek philosophy, as has generally been supposed, but in early Islamic dogmatic theology (kalām), and specifically in the ninth- and tenth-century-CE debates between Muslim dogmatists (mutakallimūn) over how the terms "thing" (šay') and "existent" (mawğüd) relate to each other. ${ }^{1}$ The present article provides evidence that gives qualified support to Jolivet's hypothesis. I argue that Jolivet is correct in highlighting the kalām background to Avicenna's essence-existence distinction, but that an important and previously overlooked testing-ground for that distinction, Avicenna's analysis of the relation between efficient and final causes, arose from an entirely Aristotelian problematic.

This article has three parts. Part 1 is an introduction to the problem. I shall survey early kalām discussions of things and existents and present evidence supporting Jolivet's hypothesis that these kaläm discussions were the backdrop against which Avicenna made his distinction between essence (māhiyya, literally "whatness," and often Latinized as "quiddity") and existence $(w u g \check{g} \bar{u} d) .{ }^{2}$ While it is easy to imagine a progression from

* Earlier versions of this article were presented at King's College London, Harvard University and Hunter College, New York. I am grateful to H. Modarressi, D. Gutas, A. Stone, I. Crystal, S. Berryman, R. Sorabji, M. Mahdi, L. Parsons, S. Menn, V. Caston and the two anonymous ASP reviewers for their comments and suggestions.

1 "Aux origines de l'ontologie d'Ibn Sīnā," in. J. Jolivet and R. Rashed (eds), Études sur Avicenne (Paris, 1984), 19-28.

${ }^{2}$ It is true that māhiyya, "quiddity," is only one of several terms - including

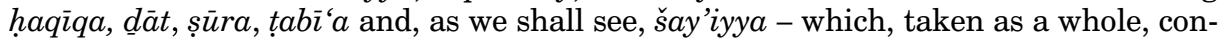
stitute Avicenna's idea of "essence" (cf. A.-M. Goichon, La distinction de l'essence et de l'existence d'après Ibn Sìnā (Avicenne) [Paris, 1937], 48). As will become clear, māhiyya is first among equals in this cluster of terms. Goichon sees $d \bar{a} t$ as the essential term for essence, following the lead of its Latin translation as essentia; mähiyya, by contrast, was rendered as quidditas. 
the mutakallimūn's use of mawğūd to Avicenna's use of wuğūd, the route from šay' to māhiyya seems less direct. I explore the possibility that the concept of thingness, šay'iyya, served to link the mutakallimūn's use of šay' and Avicenna's use of māhiyya. In Parts 2 and 3 of the article, I discuss some previously unexamined passages where Avicenna uses the term šay'iyya to explain how the final cause, al-'illa al-g'à'iyya, can be seen to be prior to the efficient cause, al-illa al-fá'iliyya. More particularly, Part 2 addresses a philological problem: whether or not these passages should be emended to read sababiyya, "causality," instead of šay'iyya, "thingness." I argue that šay'iyya should be retained. In Part 3, I discuss what šay'iyya means in the context of Avicenna's analyses of final and efficient causality. In so doing I hope to cast some light on how exactly the concept of thingness bridges the mutakallimūn's discussions of things and existents on the one hand, and Avicenna's distinction between essence and existence on the other.

\section{PART 1: ŠAY'IYYA BETWEEN ŠAY’ AND MĀHIYYA}

Given the opaque and scattered nature of most of the early sources available to us, we cannot know for sure when and where thinkers writing in Arabic first used the terms šay' and mawğùd. It is fairly certain, however, that the mutakallimūn's first discussions of things and existents arose not out of some general and spontaneous interest in ontology, but out of a desire to marshal Qur'ānic evidence in favor of their own positions and against their opponents' on two basic theological topics: God's attributes (in this case, whether or not God could be correctly spoken of as a thing, and if so, how) and God's creative power (in this case, whether or not it is things which God causes to come into existence and pass out of existence, and if so, how). In order to buttress their arguments the mutakallimūn had to address the question of what šay', "thing," refers to when it is used in the Qur'ān.

The term šay' appears in many places in the Qur'ān, and mainly refers, in a general and undifferentiated sense, to the objects of God's attributes. God is all-powerful (qadìr); over what is God all-powerful? Things, or, more precisely, every thing. Similarly, things are the objects of God's knowing (' $-l-m)$, creating $(h-l-q)$, witnessing $(\check{s}-h-d)$, being in charge of $(w-k-l)$, 
preserving ( $h-f-z)$, encompassing $(h-y-t)$, reckoning $(h-s-b)$ and supervising $(r-q-b){ }^{3}$

Despite the Qur'ān's straightforward, quasi-pronominal use of šay' (amr is used as an all-purpose direct object in much the same way), early commentators and mutakallimūn nevertheless tried to determine what precisely it meant to be a thing. For example, it seems clear enough that because things are the objects of God's attributes, they are other than God. The distinction between thing and God is reinforced by the famous verse 42:11, laysa kamitlihi šay', "No thing is [even] like a likeness of Him." Believers are also instructed not to verge towards polytheism by associating things with God $(3: 64 ; 4: 36 ; 6: 151 ; 12: 38 ; 22: 26 ; 60: 12)$. Finally, the divine act of creation is described in two famous verses, 16:40 (inna-mā qawlunā li-šay'in idِā aradnāhu an naqūla lahu kun fayakūnu) and 36:82 (inna-mā amruhu id̄ā arāda šay'an an yaqūla kun fa-yakūnu), as consisting in God's saying "Be!" to a thing, at which point the thing then is.

But the strong suggestion that things are other than God weakens slightly when one takes into account a number of verses that seem to indicate that God Himself is a thing. For example, 6:19, "Say: Which thing is the greatest in terms of witnessing? Say: God is witness between you and me" (qul ayyu šay’in akbaru šahādatan qul Allāhu šahìdun baynī wa-baynaka), implies that God is a thing, and 28:88, "Every thing will perish save His face" (kullu šay'in hālikun illā wağhahu), implies that at least the divine countenance is a thing.

This ambiguity was reinforced by the early grammarians, who held that šay' was the most generally applicable of terms ( $a^{\prime} \mathrm{a} m \mathrm{mu}$ al-'âmm), applying to all that may be placed in relation to a predicate (yaqa'u 'alā kulli mā uhbira 'anhu). ${ }^{4}$ That is,

${ }^{3} q-d-r: 2: 20,2: 26,2: 109,2: 148,2: 259,2: 284,3: 26,3: 29,3: 165,3: 189,4: 85,5: 17$, 5:19, 5:40, 5:120, 6:17, 8:41, 9:39, 11:4, 16:77, 18:45, 22:6, 24:45, 29:20, 30:50, 33:27, $35: 1,41: 39,42: 9,46: 33,48: 21,57: 2,59: 6,64: 1$, 65:12; '-l-m: 2:29, 2:231, 2:282, 4:32, $4: 176,5: 97,6: 80,6: 101,7: 89,8: 75,9: 115,20: 98,21: 81,24: 35,24: 64,29: 42,29: 62$, $33: 40,33: 54,40: 7,42: 12$, 48:26, 49:16, 57:3, 58:7, 64:11; h-l-q: 6:101, 6:102, 13:16, 16:48, 20:50, 25:2, 27:88, 32:7, 39:62, 40:62, 51:49, 54:49; š-h-d: 4:33, 5:117, 22:17, 33:55, 34:47, 41:53, 58:6 (and implied in 3:5, 14:38, 40:16); $w$-k-l: 6:102, 11:12, 39:62; h-f-z: 11:57, 34:21; h-y-t: 4:126, 41:54; h-s-b: 4:86; and $r-q-b: 33: 52$.

${ }^{4}$ Sībawayhi (d. ca. 796), al-Kitāb I, ed. I.B. Ya'qūb (Beirut, 1999), 47,7; and ap. alZabīdī, Tà̆ğ al-'arūs min ğawāhir al-qāmūs I, ed. 'A. Šìīi (Beirut, 1994), 185a20-21 and 27-28. The formulation al-šay' huwa mà yağùzu an yuhbara 'anhu is also found in al-Huwārizmì (d. 997), Mafātih al-'ulūm, ed. G. van Vloten (Leiden, 1895), 22,14-15; in that same work al-Hwārizmī reports $(199,14-200,1)$ that šay' is also used by the "Algebrists" as a kind of universal variable. 
šay' refers to every mubtada' (subject) in relation to which one could place a habar (predicate). If we want to predicate any attributes of God, therefore, we will be forced to maintain that He is a thing. This grammatical consideration seems to have overridden the weight of Qur'ànic evidence, and apart from the arch-unitarian Gahm ibn Șafwān, who - as we shall see - held to a strictly understood interpretation of thing (namely, that it was synonymous with mahlüq, "created," and that therefore God was not a thing), consensus arose around the fence-straddling assertion that God was a šay' la ka-al-ašy $\bar{a}$,, "a thing not like [other] things." 5

But whether or not it is right to call God a thing was not the only problem which the term šay' forced the early mutakallimün to confront. More seriously, the mutakallimün had to contend with the implication of verses 16:40 and 36:82 (mentioned above) that things were somehow there before God said "Be!" to them; for otherwise, what would God be saying "Be!" to? ${ }^{6}$ It seemed perfectly sensible to draw the conclusion, as most $\mathrm{Mu}$ 'tazilites did, that thing applies not only to what exists ( $\mathrm{al}$ mawğ $\bar{u} d$ ) but also to what does not exist (al-ma'dūm); and that what does not exist in turn applies not only to what did not exist and now exists, such as the world, but also to what does not now exist but will exist, such as the Day of Resurrection.

Other mutakallimūn, by contrast, held that šay' applies solely to what exists. This was partly because the $\mathrm{Mu}^{\prime}$ tazilite view could be seen as leading to two unsavory alternatives. The first arises from the premise that even before it exists one particular thing - my great-great-grandson - is and always has been distinct from another particular thing - my great-great-granddaughter. In 68 years God will say "Be!" to one non-existent thing, my great-great-grandson, and in 72 years God will say "Be!" to another non-existent thing, my great-great-granddaughter. The same premise can be applied to things that have existed but now do not. Thus my great-great grandfather, even though he is non-existent now, remains one thing, and my great-great-grandmother remains another thing, and both will

\footnotetext{
${ }^{5}$ Ps.-Abū Hanīfa (ca. 950), al-Fiqh al-akbar (= Mullā 'Alī b. Sulțān Muhammad alQārī, Śarh al-fiqh al-akbar, ed. M.M. al-Ša"ār [Beirut, 1997], 16,18).

${ }^{6}$ The term $a m r$ is used synonymously with šay' to refer to the things which God is saying "Be!" to, at 2:117, 3:47, 19:35, 36:82 and 40:68. In his Tafsì (ad 2:117) Tabari (d. 923) describes the positions of various "interpreters" (mu'awwilün) on this issue (Tafsīr al-Ṭabarī II, ed. M.M. Šākir [Cairo, 1954], 542,1-550,7).
} 
remain distinct things up to, including and (presumably) beyond the Day of Judgment. The problem is that all these preand post-existent individual things must be or subsist somewhere before and after they exist. Let us say they are all located somewhere outside God's mind; in that case they will share the attribute of eternality with God, and the precept of tawhid, understood as divine uniqueness, will be violated. Let us then say that they are all located within God's mind; in that case they will introduce multiplicity into God, and the precept of tawhìd, understood as divine simplicity, will be violated.

Aiternatively, and just as problematically, the Mu'tazilite conception could be understood as implying that before and after they exist, things were and will be undifferentiated, just one great eternal blob of Thing. In other words, when things are non-existent, they are undifferentiated; when things are existent, they are distinct one from the other. But this conception

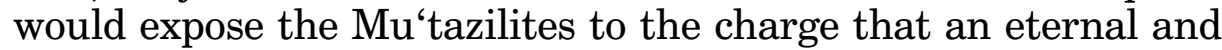
undifferentiated non-existent Thing was, for all intents and purposes, equivalent to the eternal and (in itself) undifferentiated prime matter of the Eternalists (al-dahriyya). God's sole possession of eternality is infringed upon, and the precept of tawhìd, understood as divine uniqueness, will again be violated. ${ }^{7}$

To some extent the arguments just articulated are conjecture, for as I mentioned above, contemporaneous evidence of early kalām discussions of things and existents is hard to come by. Aš'arī's Maqālāt al-islāmiyyīn contains a few typically terse descriptions of the views held by early mutakallimün:

1) A thing is something created which has a likeness (Ğahm ibn Șafwān and various Zaydīs);

2) a thing is a body (Anthropomorphists - al-mušabbiha);

${ }^{7}$ On this see H. Wolfson, "The Kalam problem of nonexistence and Saadia's second theory of creation," Jewish Quarterly Review, 36 (1946): 371-91, reprised in his The Philosophy of the Kalam (Cambridge, Mass., 1976), 359-72. The world-view of the eternalists was shaped partly by Aristotelian notions of potentiality (quwwa) and actuality $\left(f{ }^{\prime} l\right)$ then coming into circulation. See, for example, al-Kindì (d. ca. 870), Risāla fì al-ibāna 'an suğūd al-ğirm al-aqșā wa-țā'atihi li-Allāh (= R. Rashed and J. Jolivet (eds), Euvres philosophiques et scientifiques d'al-Kindī. Vol. II: Métaphysique et cosmologie [Leiden, 1998], 187,3-19), as well as the evidence preserved in the Jābirean corpus (ca. 900) (= Jābir ibn Hayyān: Essai sur l'histoire des idées scientifiques dans l'islam. Vol. 1: Textes choisis, ed. P. Kraus [Paris, 1935]) where one can detect the infiltration of notions of potentiality and actuality into the šay'/mawğùd/ma'dūm paradigm: Kitāb ikhrāğ mā fi al-quwwa ilā al-fi 'l, 2,14-3,1; Kitāb al-ḩawāṣṣ al-kabīr, 357,1-2; Kitāb al-mīzān al-șag̀ìr, 427,3-5; 431,8-11; 445,13$14 ; 451,18$. 
3) a thing is what can be pointed to (Hishām al-Fuwatīi);

4) a thing is a thing before it comes into being ('Abbād b. Sulaymān; certain Baghdadi Mu'tazilites); saying "X is a thing" is the same as affirming $\mathrm{X}$. Affirming $\mathrm{X}$ covers the time before $\mathrm{X}$ came into being as well as the time after it came into being (alKhayyāt); a thing is all that can be known, and all that can be called to mind and of which predication is possible. Things are knowable as things before they come into being. Things can be called things before they come into being (al-Ǧbbā'ì);

5) a thing is an existent (al-Aš'ari); a thing is a thing only when it exists (Abū al-Husayn al-Șāliḥī; Ibn al-Rāwandī). ${ }^{8}$

From the end of the ninth century to the end of the tenth the period, that is, just before Avicenna started writing philosophy - the mutakallimūn holding positions 1,2 and 3 became increasingly isolated, and the debate about things polarized into positions 4 and 5, with most Mu'tazilites holding position 4 and virtually everyone else - Aš'arites, Māturīdites and most Shi'ites - holding position $5 .{ }^{9}$ With God's uniqueness and sim-

${ }^{8}$ See al-Aš‘arī (d. 935), Maqālāt al-islāmiyyīn I, ed. H. Ritter (Istanbul, 1929), 158,1-163,8 and 181,1-182,4; al-Aš‘ arī, Maqālāt al-islāmiyyīn II, ed. H. Ritter (Istanbul, 1930), 518,4-519,8. Perhaps our earliest source regarding the debate over things and existents is the Zaydī Shi'ite al-Qāsim ibn Ibrāhīm (d. 860), Kitāb al-dalīl al-kabir, ed. B. Abrahamov (Leiden, 1990), 74,10-76,7.

${ }^{9} \mathrm{Mu}$ 'tazilites: al-Khayyāt (d. ca. 913), Kitāb al-intișār, ed. H.S. Nyberg, (Cairo, 1925), 60,4-14; 107,6-108,8; 126,1-2; Sa'diyā al-Fayyūmī (i.e. Saadia Gaon, d. 942), Kitāb al-amānàt wa al-i 'tiqādāt, ed. S. Landauer (Leiden, 1880), 11,10-12 and 213,1315; 'Abd al-Ğabbār (d. 1025), al-Mug̀nī fì abwāb al-tawhìd wa al-'adl, ed. M.M. Ḥilmī et al. (Cairo, 1958f.), IV 247,12-13; V 202,8-203,9; 249,4-8; 251,3-4; 252,4-6; VI/1 79,17-80,15; VI/2 75,5-77,7 and 135,3-136,9; VIII 74,1-82,12; XII 20,1-3 and 48,5-6. Aš‘arites: Ibn Fūrak (d. 1015), Muğarrad maqālāt al-Aš ‘arì, ed. D. Gimaret (Beirut, 1987), 42,7-18 and 252,4-256,22; and al-Bāqillānī (d. 1013), Kitāb al-tamhìd, ed. R.J. McCarthy (Beirut, 1957), 193,17-194,6; 195,6-196,12; 266,4-9. (In fact, al-Aš‘arī admitted in his Kitāb al- 'amad that he himself had originally held the Mu'tazilite position: "We wrote a book on the topic of "thing," namely, that things are things even if they be non-existent. We have retreated from it [i.e. the position articulated in this book] and [now] contradict it, so whoever comes across it [the book], let him not place any store by it"; reported by Ibn 'Asākir, Tabyīn kadib al-muftarì fì-mā nusiba ilā al-Imām Abì al-Hasan al-Aš arī, no ed. [Damascus, 1928], 133,5-6.) Māturīdites: al-Māturīdì (d. ca. 944), Kitāb al-tawhìd, ed. F. Kholeif (Beirut, 1970), 39,20-43,21; 86,2-92,20; 104,8-106,18; 242,3-16; and Abù al-Layt al-Samarqandì (d. ca. 990), Sarh al-fiqh al-absat li-Abi Hanifa, ed. H. Daiber (as The Islamic Concept of Belief in the 4th/10th Century) (Tokyo, 1995), 119,1-2 (= lines 426-7). Shi'ites: al-Shaykh al-Mufid (d. 1022), Awā'il al-maqālāt fì al-mad̄āhib wa-al-muhtārāat, ed. M. Muhaqqiq (Tehran, 1993), 42,14-19. See also R.M. Frank, "Al-ma'dūm wal-mawjūd," MIDEO, 14 (1980): 185-210; and now his "The Aš‘arite ontology: I Primary entities," Arabic Sciences and Philosophy, 9/2 (1999): 163-231; A. Dhanani, The Physical Theory of Kalām (Leiden, 1994), 27 n.4 and 29-30; M.J. McDermott, The Theology of al-Sayh 
plicity at stake, not to mention the nature of His causation of the world, the primitive dogmatic formulae devised to encapsulate these two positions grew into fully articulated school doctrines. The kalām discussion of things and existents came to encompass general questions of ontology, and the metaphysical notions used in the debate became more sophisticated.

This increase in complexity went hand in hand with the intensifying philosophical activity of the period, activity that involved translating Greek philosophical texts into Arabic as well as composing original philosophical works in Arabic. In his Kitā $b$ fì al-falsafa al-ülā, Kindī uses the term šay' in a brief discussion of essence, existents and non-existents, but for the latter three terms he uses $\underline{d} \bar{a} t$, ays and lays respectively. ${ }^{10}$ Fārābi was the first faylasūf to incorporate the term māhiyya ("whatness," "quiddity" or simply "essence") - a term deriving primarily from the rendering of the Greek to ti én einai as $m \bar{a}$ huwa in the Arabic translations of Aristotle's logical works into the kalām problematic of things and existents. ${ }^{11}$ Fārābi

al-Mufid (Beirut, 1978), 196-9; F. Klein-Franke, "The non-existent is a thing," Le Muséon, 104 (1994): 375-90; D. Gimaret, Les noms divins en Islam (Paris, 1988), 142 50; and J. van Ess, Theologie und Gesellschaft im 2. und 3. Jahrhundert Hidschra (Berlin, 1991-1997), I 357f.; II 481f. and 499-501; IV 45-9 and 432-5.

${ }^{10}$ Euvres philosophiques et scientifiques d'al-Kindī II, 41,3-43,18.

${ }^{11}$ It is true that to ti én einai (and its variants) was translated as mähiyya only rarely, and primarily in the context of distinguishing definition (al-hadd) from property (al-hāsș̣a): the former is a statement that "indicates the thing's essence" (al-dāll 'alā māhiyyat al-šay'), the latter one that does not. See, for example, Top. 101b38102a1 (= Țübìka, in Manțiq Arisțū II, ed. 'A. Badawī [Cairo, 1949], 474,17); 102a21 (= 475,14); 103b10-11 (= 481,11); and 154a30 (= Manțiq Arisțū III, ed. 'A. Badawī [Cairo, 1952], 685,12-13). In the Organon to ti èn einai was mostly translated as $m \bar{a}$ huwa. See, for example, An. Post. 83a21 (= Taḥlìlāt țāniyya, in Manțiq Arisțū II, $375,6) ; 83 \mathrm{~b} 5(=376,14) ; 84 \mathrm{a} 26(=380,8)$; $97 \mathrm{a} 25(=448,5)$ and $97 \mathrm{~b} 2(=449,4)$; 102a3233 (= 476,12); 103b21.30.34 (= 482,4.12.15); 120b21 (= 552,15); 122a5-6.1219.21.32.36 ( = 557,18, 558,6-11.13 and 559,4.8.9.10.11 bis); $128 \mathrm{a} 14.19$ ( $=581,15$ and $582,1)$ and 148a1 $(=656,8)$. It is also translated as mā huwa al-šay': An. Post. 79a25.27.29 (= Taḥlìlāt țāniyya, 354,2.4.5) and Top. $101 \mathrm{~b} 22$ (= Ṭūbìka, 474,1); and as mā al-šay': An. Post. $82 \mathrm{~b} 37$ (= Tahlìlāt țāniyya, 373,15); and Top. 101b21 (= Ṭūbìka, 473,17); Top. 103b24.26 (= Tübìka, 482,8.9) and 148a1 (= 656,7). In the Metaphysics, to ti èn einai was translated as mà huwa at 994b17 ( = Mà ba'da al-tabí ' $a I, 34,8)$ and 993a18 ( $=I, 161,13)$; as mà hiya and $m \bar{a}$ al-šay' at 1016a33-34 (= II, 536,5-6); as mā huwa al-šay' at 994a11 (=I, 17,3); as mà anniyyat al-šay' at 1024b29 (= II, 685,1); and as mà kaynūnat al-šay' at 1013b22 (=II, 487,14). Mostly, however, to ti èn einai in the Metaphysics was translated as mā huwa bi al-anniyya: at 1025b29-29 (= II 705,8); 1030a6 (= II 795,10); 1030a17 (= II 798,6); 1030a29 (= II 802,6); 1031a9-10 (= II 818,10); 1031a18 (= II 821,16); 1031b30 (= II 831,7); $1033 \mathrm{~b} 7$ (= II 860,15-16); $1035 \mathrm{~b} 16$ (= II 903,8); 1037a21 (= II 936,8-9); 1037a33-b1 (= II 939,15); 1044a36 (= II 1074,1); 1045b3 (= II 1096,13); and 1075a2 (= II 1693,1). 
appears at first glance to come down on the side of the $\mathrm{Mu}$ 'tazilites on the issue of whether or not thing was a more overarching category than existent, but closer examination reveals that his view is more nuanced. Fārābi first establishes that his definition of mawğūd as "that which, outside the soul, is set apart by some essence, be it conceived of or not" ( $m \bar{a}$ huwa munḥ̄àun bi-māhiyyatin mā ḩāriğa al-nafsi tuṣuwwirat aw lam tutașawwar), is broader and hence more basic than the other definitions of mawğ 'ud he suggests. ${ }^{12}$ Fārābì defines šay', on the other hand, as "all that possesses some essence, in whichever way, be it outside the soul or conceived of in any sense whatsoever, divided up or undivided" (kullu mā lahu māhiyyatun mā kayfa kāna ḩāriğa al-nafsi aw kāna mutașawwaran 'alā ayyi ğihatin kāna munqasimatan aw ġayra munqasimatin). ${ }^{13}$ Thus defined, mawğ $\bar{u} d$ is not as broadly applicable as šay', because šay' covers essences both outside and inside the mind, whereas mawğ $\bar{d} d$ covers merely those outside the mind. In this sense Fārābì appears to be echoing the $\mathrm{Mu}$ 'tazilite position.

On the other hand, Fārābì again follows the Arabic translations of the Organon and argues that mawğùd has one technical use that šay' does not: as the copula (rābit) that connects the subject (here the logical term al-mawdi $\bar{u}^{\prime}$ as opposed to the grammatical term al-mubtada') to the predicate (al-mahmūl as opposed to al-habar) in categorical affirmative propositions (alaqūwīl al-ğàzima al-mūğiba). ${ }^{14}$ For example, Fārābī says, when we wish to state that Zayd is a just person, it might make sense to say, literally, "Zayd is found to be a just person" (Zaydun mawğ $\bar{u} d u n$ 'ádilan), while it makes no sense to say "Zayd is thing a just person" (Zaydun šay'un 'ádilan). In this technical, copulative sense, mawğ $\bar{u} d$ is more broadly applicable than šay', although Fārābi stresses that the first, non-copulative sense of mawğ $\bar{u} d$ is more basic. As he did with māhiyya, Fārābī has tried to incorporate an Aristotelian notion - here the copulative or predicative sense of to einai, "to be" - into the kalàm problematic of šay' v. mawğūd. ${ }^{15}$ To sum up Fārābì's position, then, šay'

${ }^{12}$ Al-Fārābī, Kitāb al-ḥurūf, ed. M. Mahdī (Beirut, 1969), 116,23-117,1.

${ }^{13}$ Al-Fārābī, Kitāb al-ḥurūf, 128,6-8.

${ }^{14}$ Al-Fārābī, Kitāb al-h̆urūf, 125,12-13.

${ }^{15}$ Al-Fārābī, Kitāb al-ḥurūf, 128,12-13. In Metaph. 4.2, 1003b10 (= Averroes, Tafsīr Mā ba'da al-tabī 'a I, ed. M. Bouyges [Beirut, 1938], 301,9-10) Aristotle claims that we can say that even something that is non-existent ( $t o m \bar{e}$ on = alladì laysa bi- 
is more broadly applicable than mawğūd in the first, more basic sense, yet less broadly applicable than mawğūd in the second, more technical sense.

The kalām discussions of things and existents and Fārābī's efforts to Aristotelianize them provide the backdrop for an important discussion in Ilāhiyyāt 1.5 of Avicenna's Kitāb alšifă', where Avicenna seems to be making a distinction between essence and existence. ${ }^{16}$ In Ilähiyyāt 1.5 Avicenna attempts to make the following points. First $(29,5-31,2)$, he argues that thing and existent are primitive, basic and immediately apprehensible concepts. Because there are no terms more broadly applicable than thing and existent, they are indefinable, in the Aristotelian sense of definition at least; that is, there is no genus under which they can be subsumed as species. Second (31,2-32,3), Avicenna shows that thing and existent have different meanings. "Thing" is associated with terms such as "inner reality" (haqiqqa) and "whatness" (māhiyya), and appears to refer to an entity viewed in light of essence; "existent" is associated with terms such as "affirmed" (mutbat) and "realized" (muhașsal), and appears to refer to an entity viewed in light of existence. Third (32,3-34,14), Avicenna explains that although they have different meanings, thing and existent are co-implied (mutalāzimāni). In this context, Avicenna's purpose in describing šay' and mawğüd as co-implied seems to be to convey the idea that although they have different meanings, neither šay' nor mawğ $\bar{u} d$ is more broadly applicable than the other; the domains of objects to which each term refers fully overlap. The reflexivity inherent in the sixth-form term taläzum has important connotations as far as Avicenna's distinction between essence and existence is concerned. For at least in this context, Avicenna is saying that neither šay' nor mawğūd is logically prior to the other. There is no hint here that being an existent is somehow subordinate to, or an accident of, being a thing.

huwiyyatin) in some sense is non-existent (einai mè on = fa-innahu laysa huwiyyatan). Generally speaking, to on in the Metaphysics was translated into Arabic not as almawğūd but as al-huwiyya ("being"). Fārābì's analysis is discussed by Jolivet, "Origines," 17; S. Abed, Aristotelian Logic and the Arabic Language in Alfārābī (Albany, N.Y., 1991), 111-17; F. Zimmermann, Al-Fārābì's Commentary and Short Treatise on Aristotle's De Interpretatione (London, 1981), xliv-xlv, lx-lxiii and cxxxcxxxiv; and F. Shehadi, Metaphysics in Islamic Philosophy (Delmar, N.Y., 1982), 45-69.

${ }^{16}$ Kitāb al-šifă': al-Ilāhiyyāt, eds G. Qanawātī and S. Zāyid (Cairo, 1960), 29,534,14 . 
To sum up, then, the debate in the tenth century came to turn on how things and existents relate to each other both extensionally (that is, whether or not the domain of things overlaps with the domain of existents) and intensionally (that is, whether or not thing and existent have the same meaning). Logically speaking, these were the options:

1) thing and existent are mutually exclusive both extensionally and intensionally: "things are never existents and existents are never things; to be a thing and to be an existent have different meanings" (no one from this period seems to have held this view);

2) thing is subsumed extensionally but not intensionally under existent: "things are always existents but existents are not always things; to be a thing and to be an existent have different meanings" (no one from this period seems to have held this view);

3a) existent is subsumed extensionally but not intensionally under thing: "existents are always things but things are not always existents; to be a thing and to be an existent have different meanings" (most Mu'tazilites);

3b) existent is subsumed extensionally but not intensionally under thing*: "existents are always things but things are not always existents (*although mawğūd can be used as a copula whereas šay' cannot); to be a thing and to be an existent have different meanings" (Fārābī);

4a) thing and existent are identical both extensionally and intensionally: "things are always existents, and existents are always things; to be a thing and to be an existent have the same meaning" (Ǎš'arites, Māturīdites and most Shi'ites);

4b) thing and existent are identical extensionally but different intensionally: "things are always existents, and existents are always things; to be a thing and to be an existent have different meanings" (Avicenna).

The debt Avicenna owes to the kalām discussions of things and existents seems self-evident, given the similarity of his position to that of the Aš'arites, Māturīdites and most Shi'ites (from now on I will use the abbreviation AMS for this position). In this regard Jolivet is surely correct. But more precisely, Avicenna's position in Ilāhiyyāt 1.5 seems to be a compromise between AMS on the one hand, and the Mu'tazilites' and Fārābī's position on the other. For although Avicenna advocates the extensional identity of thing and existent just as AMS does, 
he also advocates the intensional difference between thing and existent just as the $\mathrm{Mu}$ 'tazilites and Fārābī do.

Nevertheless, Jolivet reckons that the influence of the mutakallimūn was greater than that of the Aristotelian philosophers because no Greek antecedent can be found for šay' (pragma is the possibility Jolivet explores and rejects), in contrast to mawğ $\bar{u} d$, whose roots lie in the Greek term to on (and similarly ta onta for mawğūdàt, and to einai for wuğūd). ${ }^{17}$ Although Jolivet is correct in asserting that to on is the Greek equivalent of mawğ $\bar{u} d$, and that pragma is not the Greek equivalent of šay', the fact remains that a Greek antecedent for šay' does exist: $t i$ ("something"). In fact, the question of the ontological status of the non-existent - to mé on - and its relation to the something - to ti - has an ancient pedigree. The problem originates with Parmenides, is discussed at length by Plato in the Sophist, is analyzed by Aristotle in the Metaphysics and the Physics, and emerges as a coherent ontology among the Stoics, who - like the Mu'tazilites and Fārābī - put "something" ( $t i$ ) at the top of their ontological pyramid, above even "existent" (to on). ${ }^{18}$

${ }^{17}$ Jolivet, "Origines," 15-16. On this see also P. Hadot, "Sur divers sens du mot pragma dans la tradition philosophique grecque," in P. Aubenque (ed.), Concepts et catégories dans la pensée antique (Paris, 1980), 309-19.

18 Parmenides, fr. VI, lines 1-2 (esti gar einai, mēden d'ouk estin - "There is being, but there is no nothing") and VII,1 (ou gar mépote touto damēi einai mé eonta - "That there are non-existent things will never be proven") (In fact, Parmenides comes across as a proto-Aš‘arite when Fārābi quotes him as asserting that "All that is nonexistent is not a thing" - wa-kullu mā huwa ġayru mawğūdin fa-laysa bi-šay'in: alFārābī, Kitāb al-hurūf, 128,19); Plato, Sophist 236E onwards; Aristotle, Metaph. 4.2, $1003 \mathrm{~b} 10$ (At Metaph. 14.2, 1089a5-28, Aristotle argues that Plato's conception of to $m \bar{e}$ on as "the false" - to pseudos - is useless in explaining generation and corruption, and proposes that a better conception of to $m \bar{e}$ on is "the potential" - to kata dunamin - a position followed explicitly by Fārābì, K. al-hurüf, 120,8-121,6 and 123,1-124,4; see also Aristotle's distinction between absolute and incidental non-existence in Phys. 1.8 and 1.9, 191a23-192b7). On the Stoic ontology, and on the way in which incorporeals are said to "subsist" rather than "exist," see P. Hadot, "Zur Vorgeschichte des begriffes Existenz: huparkhein bei den Stoikern," Archiv für Begriffsgeschichte, 13 (1969): 115-27; A. Graeser, "À propos huparkhein bei den Stoikern," Archiv für Begriffsgeschichte, 15 (1971): 299-305; V. Goldschmidt, "Huparkhein et huphistanai dans la philosophie stoïcienne," Revue des Études Grecques, 85 (1972): 331-44; P. Pasquino, "Le statut ontologique des incorporels," in J. Brunschwig (ed.), Les Stoïciens et leur logique (Paris, 1978), 375-86; J. Brunschwig, "The Stoic theory of the supreme genus and Platonic ontology" and "On a Stoic way of not being," both originally published in French (as "La théorie stoïcienne du genre suprême et l'ontologie platonicienne," in J. Barnes and M. Mignucci (eds.), Matter and Metaphysics: Fourth Symposium Hellenisticum (Naples, 1988), 19-127, and "Sur une façon stoïcienne de ne pas être," Revue de théologie et de philosophie, 122 [1990]: 389-403) and 
It would be tempting to assert a Stoic link here, but tracing Stoic influence on Arabic kalām and falsafa has always been a tricky business; many scholars have tried, with varying degrees of success. ${ }^{19}$ Less uncertain is the influence Stoicism had on the Greek Aristotle-commentators, whom the Arabic philosophers read carefully. For example, in his commentary on Book 4, Chapter 1 of Aristotle's Topics, Alexander of Aphrodisias criticizes the Stoics for elevating "something" above "existent":

Here is a way you can demonstrate how wrong the Stoics are in holding that "something" is the genus under which "existent" is subsumed: if it is a something, it will clearly be an existent as well; and if it is an existent it will be definable as existent. Now they wriggle out of this dilemma by holding that "existent" is said of bodies alone, and on this basis they speak about "something" being a higher genus than it, given that it ["something"] is predicable of incorporeal as well as corporeal entities. ${ }^{20}$

Now any attempt to use this particular passage as evidence of a

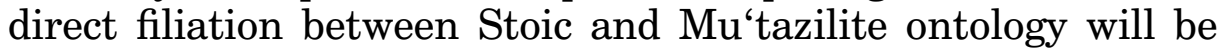
frustrated by the fact that only Alexander's comments on part of Book 1 and Books 5-8 of the Topics survive, at least according to Ibn al-Nadim. ${ }^{21}$ But elsewhere in Alexander's commentary on the Topics, as well as in Simplicius' commentary on the Categories, the Stoic ontology is articulated, although less starkly than in the in Top. 4.1 passage just translated. ${ }^{22}$ To sum up: Jolivet is correct in asserting that the kalām discussions of things and existents were likely to have been the most important (and certainly the most immediate) influences on Avicenna, but wrong in reasoning that this was because ancient philosophers had no such discussions.

translated into English by J. Lloyd in Brunschwig's Papers in Hellenistic Philosophy (Cambridge, 1994), 92-157 and 158-169; and now V. Caston, "Something and nothing: The Stoics on concepts and universals," Oxford Studies in Ancient Philosophy, 17 (1999): 145-213.

${ }_{19}$ e.g. F. Jadaane, L'influence du stoïcisme sur la pensée musulmane (Beirut, 1968), 43-98; J. van Ess, Die Erkenntnislehre des 'Aḍudaddīn al-Īcī (Wiesbaden, 1966), 191200; Wolfson, The Philosophy of the Kalam, 355-72; S. Pines, Beiträge zur islamischen Atomenlehre (Berlin, 1936), 116-17; these are reviewed briefly by Gutas in his "Pre-Plotinian philosophy in Arabic (other than Platonism and Aristotelianism): a review of the sources," Aufstieg und Niedergang der römischen Welt, II.36.7 (Berlin, 1994), 4939-73, at 4959-62.

${ }^{20}$ Alexander, in Top. 4.1 (ad 121a10), CAG II, 301,19-25.

${ }^{21}$ Ibn al-Nadīm, Kitāa al-fihrist, ed. G. Flügel (Leipzig, 1871), 249,17-19.

${ }^{22}$ Alexander in Top. 42,37 and 359,12-16; Simplicius in Cat., CAG VIII, 105,7-20; 209,$10 ; 222,30-33 ; 333,31$. 
Having briefly dealt with the question of Greek antecedents, I can focus on the question of how exactly the kalām discussions of things and existents influenced Avicenna's distinction between essence and existence. For while it is easy enough to imagine his making the move from mawğ $\bar{d} d$ to wuğudd, less obvious is Avicenna's progression from šay' to mähiyya, the term he uses most consistently to describe essence when contrasting it with existence. To some extent Avicenna's progression from šay' to mähiyya can be reconstructed by analyzing the Ilāhiyyāt 1.5 passage devoted to showing how thing and existent have different meanings. In that passage Avicenna starts by asserting that every thing (šay') or entity (amr) has an inner reality (haqiqa) by which it is what it is $(31,5-6)$. This inner reality (e.g. triangularity) is sometimes called "existence that is specific" (al-wuğ $\bar{u} d$ al-ḩasșs); specific, that is, to one class of things (triangles) as opposed to another class of things (cats). Existence that is specific is distinct from the more general type of existence which Avicenna calls "affirmative existence" (al$w u \check{g} \bar{u} d$ al-ithōtī) (31,7-8). To predicate affirmative existence of an entity is to assert that the entity is, not what the entity is. To predicate existence that is specific, on the other hand, is to assert what the entity is, not that the entity is. Since existence that is specific is identical to inner reality, and inner reality is identical to whatness ( $m \bar{a} h i y y a)$, it follows that existence that is specific is identical to whatness $(31,10)$. And since existence that is specific is identical to whatness, and existence that is specific is distinct from affirmative existence, it follows that whatness is distinct from affirmative existence. In other words, essence is distinct from existence. ${ }^{23}$

A brief remark later on in Ilāhiyyāt $1.5(33,16-18)$ raises the intriguing possibility that šay'iyya, thingness, served to link Avicenna's distinction between things and existents on the one hand and his distinction between essence and existence on the other:

According to people who hold this view [that what is predicated can be a non-

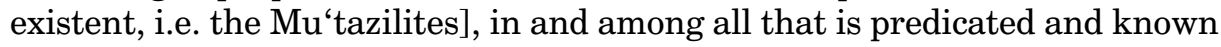
are some entities [umür] that, when non-existent, possess no thingness

\footnotetext{
${ }^{23}$ Avicenna's discussion of things and existents in Ilāhiyyāt 1.5 is related to similar treatments in Aquinas' work by I. Craemer-Ruegenberg, "Ens est quod primum cadit in intellectu' - Avicenna und Thomas von Aquin," in U. Tworuschka (ed.), Gottes ist der Orient - Gottes ist der Okzident (Köln, 1991), 133-42.
} 
(šay'iyya); let the person who is inclined to agree with that go back to whatever dogmatic formulae they babbled out unintelligibly, [formulae] which do not deserve any attention.

In this passage Avicenna is attacking those who maintain that there is a class of non-existent entities that possess no thingness, and hence are not things. A later commentator on the Ilāhiyyāt, Mullā Mahdī Narāqī (d. 1764), advises us that Avicenna's target here was a group of $\mathrm{Mu}^{\text {'tazilites who, in }}$ maintaining that some non-existents (those that are impossible, al-mustahìlāt or al-mumtani 'àt) had no thingness and hence were not things, deviated from the classical doctrine of their school. $^{24}$

Despite Avicenna's use of the term šay'iyya here, any attempt to prove that the term served to bridge the ninth- and tenthcentury-CE kaläm discussions of things and existents on the one hand, and Avicenna's discussions of essence and existence on the other, will face two difficult challenges. The first challenge is that šay'iyya would play a bridging role more convincingly if that term had appeared often and in a wide variety of ninth- and tenth-century kalām texts. It does not. In fact, I have not seen a single instance of šay'iyya where I most expected to find it: in a text written by a Mu'tazilite, a member of the school most infamous for affirming the thingness of the non-existent. Nor does šay'iyya seem to appear in an Aš'arite text until Guwaynī, that is, not until a generation after Avicenna's death. ${ }^{25}$

${ }^{24}$ Mullā Mahdī Narāqī, Šarh al-ilāhiyyāt min kitāb al-šifā', ed. M. Muhaqqiq (Tehran, 1986), 265,2. M. Marmura ("Avicenna on primary concepts in the Metaphysics of his al-Shifā,", in R. Savory and D. Agius (eds), Logos Islamikos: Studia islamica in honorem Georgii Michaelis Wickens [Toronto, 1984], 219-39; revised slightly in his "Avicenna and the Kalām," ZGAIW, 7 [1991/1992], 172-206) argues that what troubled Avicenna specifically was the Mu'tazilite Abū Hāšim's and his followers' application of their šay'/mawğ $\bar{u} d / m a ' d \bar{u} m$ paradigm to the problem of bodily resurrection. Also see D. Black's discussion of the dilemmas that faced Avicenna in distinguishing between fictional entities such as phoenixes, which seem to have some kind of mental existence even though they never exist as concrete objects in the outside world, and impossibilities such as a square circle, which seem to have neither mental nor concrete existence: "Avicenna on the ontological and epistemic status of fictional beings," Documenti e studi sulla tradizione filosofica medievale, 8 (1997): 425-53.

${ }^{25}$ Strangely enough, Ğuwaynī devoted a long section of his $\check{S}$ āmil to reviewing the debate about things and existents, yet does not once use the term šay'iyya there: alŠàmil fì uṣull al-dīn, ed. 'A.M. 'Umar (Beirut, 1999), 23,18-33,24; but see his use of the term in other contexts, at 113,2.4; 161,25.26.27; and 169,6.17. Šahrastānī uses 
But šay'iyya does make a few appearances in the tenth century. It turns up once (in a passage attributed to Ğa'far al-Ṣādiq (d. 765) commenting on the credal formula šay' lā $k a$ $a l$-ašy $y$ ', "[God is] a thing not like [other] things") in the Kāfi of the Shi'ite traditionist Abu Ğa'far al-Kulaynī (d. 940). ${ }^{26}$ It is only in the Kitâb al-tawhìd of al-Māturīdì (d. 944) however, that šay'iyya is also used consistently to describe and attack the doctrine of the $\mathrm{Mu}^{\text {'tazilites. }}{ }^{27}$ Later in the tenth century, Māturìdī's use of šay'iyya in the context of anti-Mu'tazilite polemics was echoed in the Sarh al-fiqh al-absat li-Abì Haniffa of the Hanafite scholar Abū al-Layt al-Samarqandī (d. 990). ${ }^{28}$

Are these appearances of šay'iyya the first uses of the term, or are they evidence of earlier Mu'tazilite use? At this stage of research it is difficult to tell. With such a tiny proportion of what was written by ninth- and tenth-century mutakallimün now available to us, assertions about the term's history will inevitably suffer from tentativeness. But the fact that the term seems to be absent from the few Mu'tazilite and Aš'arite sources we do have from this pre-Avicennian period indicates that Māturīdī might well deserve the honor of being called $A b \bar{u}$ šay'iyya. What is interesting here is that because Avicenna grew up outside Buhārā - that is, in Transoxania, an area where the Samarqandī Ḥanafism of al-Māturīdī was strong - and because he was taught jurisprudence by a Hanafite scholar called Ismā‘̄il al-Zāhid, Avicenna may well have come across the term šay'iyya during his youthful fiqh studies, if not in Māturīili's Kitāb

šay'iyya in several places: Kitāb nihāyat al-iqdām fì 'ilm al-kalām, ed. A. Guillaume, no date, 33,20; 73,17; 150,7.8.10; and 151,2.7. For an argument that Šahrastāni is more properly described as an Ismā'ìlì, rather than an Aš‘arite, see D. Steigerwald, La pensée philosophique et théologique de Shahrastānī (Québec, 1997). Gazālī himself mentions the Mu'tazilite view without using šay'iyya: Tahāfut al-falāsifa, ed. M. Bouyges (Beirut, 1927), 358,8-11.

${ }^{26}$ Abū Ğa'far Muhammad b. Ya'qūb al-Kulaynī, al-Ușūl min al-kāfì, ed. 'Alī Akbar al-Gaffārī (Tehran, 1961), 82,4-85,9 at 83,6-8. In Ibn Bābawayh's slightly later collection of Imāmī Shi'ite sayings, šay'iyya is also used in the context of affirming that God is a thing unlike other things, except this time in a passage attributed to Ga'far al-Șādiq's son, Mūsā al-Kāzim: Abū Ga'far Muhammad ibn Bābawayh al-Ṣadūq, Kitāb al-tawhìd (Bombay (?), 1903), 94,9-95,1.

${ }^{27}$ Māturīìi, Kitāb al-tawhìdd, 41,10 bis.15; 86,3.16; 104,10.11.12.15; 132,19; 238,9.10; 242,8.9.11.12.13.14 bis.18. See D. Gimaret's brief discussion of Māturīdī's use of šay'iyya, in his Théories de l'acte humain en théologie musulmane (Paris, 1980), 182-184 and 203.

${ }^{28}$ Abū al-Layt al-Samarqandī, Šarh al-fiqh al-absat li-Abì Hanīfa, 119,1.2 (= lines 426-7). 
al-tawhìd, then perhaps in Abū al-Layt al-Samarqandī's commentary on Abū Hanīfa's al-Fiqh al-absat. Even if Ismā'īl alZāhid himself was not a Māturīdite in kalām (Buhāran Hanafites tended to be less rationalistic and speculative in kalàm than those in Samarqand, and in any case there were Hanafites such as Ibn Fūrak who were Aš'arite in kalām), it is perfectly possible that Ismā'íl could have used a simple commentary such as Abū al-Layt's when teaching his young student the Hanafite creed. ${ }^{29}$

Of course it is also perfectly possible that Avicenna came up with the term šay'iyya all by himself. Others have remarked on Màturīdī's predilection for abstract nouns ending in -iyya, an extreme example being his grafting of the Arabic -iyya (equivalent to the English "-ness," or the Latinized "-ity") onto the Persian hast ("be") to form hastiyya ("being"). ${ }^{30}$ Māturīdī's predilection for abstract nouns was a trait Avicenna certainly shared. But given the presence of the term šay'iyya in a small number of tenth-century kalām texts as well as in Avicenna's Ilāhiyyāt 1.5, there is a possibility - nothing more - that the term played a bridging role between the earlier kalàm discussions of things and existents and Avicenna's distinction between essence and existence.

The second challenge to my hypothesis still remains to be met. For even if future research is able to establish a firmer link between kalàm uses of the term šay'iyya and Avicenna's own use of it in Ilähiyyāt 1.5, the fact remains that the concept of what it is to be a thing (of thingness, in other words) which Avicenna articulates in Ilāhiyyāt 1.5, appears to be inconsistent with his discussions of things elsewhere. More importantly, Avicenna's concept of thingness in Ilähiyyāt 1.5 does not seem to mesh with his concept of māhiyya, or essence. Despite Avicenna's clear assertion in Ilāhiyyāt 1.5 that thing and exis-

\footnotetext{
${ }^{29}$ On Avicenna's Hanafite education, see D. Gutas, "Avicenna's madhab with an appendix on the question of the date of his birth," Quaderni di studi arabi, 5-6 (19871988): 323-36. On Ismā'īl al-Zāhid, see W. Gohlman (ed. and trans.), The Life of Ibn Sina (Albany, N.Y., 1974), 20,4-7, and al-Hatịib al-Bag̉ādī, Tārīh Bağdād 6, no ed. (Beirut, 1968), 310,17-311,18 (= \#3355). On Māturīdism in Transoxania, see W. Madelung, "The spread of Māturīdism and the Turks," Actas do IV Congresso de Estudos Árabes e Islâmicos Coimbra-Lisboa 1968 (Leiden, 1971), 109-68, and his article "Māturīdiyya," $E I^{2}$, vi, 847, and now U. Rudolph, al-Māturīdì und die sunnitische Theologie in Samarkand (Leiden, 1996).

${ }^{30}$ Rudolph, al-Māturīdì, 212-13; compare al-Fārābī, Kitāb al-ḥurūf, 111,17-21.
} 
tent are co-implied (mutalāzimāni) and extensionally identical, there are several discussions of essence and existence elsewhere in the Ilähiyyāt and in other works from Avicenna's middle period, which suggest that šay' - and māhiyya, as we shall see is at the very least logically prior to mawğ $\bar{u} d$, and perhaps even a broader category than mawğūd. If šay' is logically prior to mawğüd, then Avicenna's assertions about the reciprocal nature of the co-implication (talāzum) between thing and existent - so clearly articulated in Ilähiyyāt 1.5 - will be undermined. Even more seriously, if šay' is a broader category than mawğ $\bar{u} d$, then their extensional identity will be repudiated.

The following are summaries of the relevant passages, including Ilāhiyyāt 1.5, in chronological order:

1) Madhal 1.2: The essences of things (māhiyyāt al-ašyā') are sometimes found in concrete objects in the outside world, and other times are conceived of in the mind. But essence has three aspects: as a concrete, external existent; as a mental, internal existent; and a third aspect, in which it is unrelated to either concrete or mental existence. ${ }^{31}$

2) Madhal 1.12: Genera and species may be divided into those which are before a state of multiplicity (that is, those contained in the active intellect and the other celestial intellects), those which are in a state of multiplicity (that is, those contained individually in sublunary concrete existents), and those which are after a state of multiplicity (that is, those contained as abstracted universals in human intellects). Taken in itself a genus or a species is a thing. "Animal," taken in itself, is an object ( $m a$ 'nan), regardless of whether it is a concrete or a mental existent, or whether it is general or specific. ${ }^{32}$

3) Ilāhiyyāt 1.5 (discussed above): "Thing" and "existent" are primary, indefinable categories. Whatever is predicable of thing will also be predicable of existent, and whatever is predicable of existent will also be predicable of thing. Although they are coimplied, thing and existent have different meanings.

4) Ilāhiyyāt 5.1: A universal (kullī) such as "horseness,"

${ }^{31}$ Kitāb al-šifā': al-Manțiq (1)/al-Madhal, eds G. Qanawātī, M. al-Khudayrī and F. al-Ahwānī (Cairo, 1952), 15,1-7.

${ }^{32}$ Madhal 1.12, 65,4-12. On this passage see M. Marmura, "Avicenna's chapter on universals in the Isagoge of his Shifä'," in A. Welch and P. Cachia (eds), Islam: Past Influence and Present Challenge (Edinburgh, 1979), 34-56. 
taken in and of itself ( $f i$ nafsihi) - that is, without considering

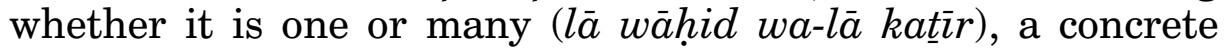
existent in the outside world or a mental existent inside the soul ( $l \bar{a}$ mawğ $\bar{u} d$ fi al-a'yān wa-lā mawğùd fì al-nafs), in potentiality or in actuality ( $l \bar{a}$ bi-al-quwwa wa-lā bi-al-fi' $l$ ) - is a thing $\left(\right.$ ša $\left.{ }^{\prime}\right){ }^{33}$

5) Ilāhiyyāt 7.1: "One" (al-wāhid) and "existent" (al-mawğūd) are equally predicable of things (qad yatasāwiyāni fi al-ḥaml 'alā al-ašyō'); all that may be characterized by "one" may also be characterized by "existent," but the two terms do not have the same meaning as each other. ${ }^{34}$

6) Nağàt/Ilāhiyyāt 1.9: "One" is a necessary accident of things (min al-a'rād al-lāzima li-al-ašyō'). Essence is a thing (bal takūnu al-mähiyya šay'an), be it a man or a horse, an intellect or a soul; that thing is only subsequently characterized as being one or existent. ${ }^{35}$

From these passages a discrepancy seems to emerge over the issue of what exactly is it to be a thing; over the question, that is, of thingness. The message from the Ilähiyyāt 1.5 passage discussed above at length is that thing and existent are extensionally identical yet intensionally different. In other words, while thingness and existence have different meanings, neither term

${ }^{33}$ Ilāhiyyāt 5.1, 196,6-13.

${ }^{34}$ Ilāhiyyāt 7.1, 303,6-12. Avicenna's assertion that mawğ $\bar{u} d$ and wāhid are extensionally identical but intensionally different almost certainly derives from Aristotle's discussions in Metaph. 4.2, 1003b22-1004a2 (contained in Tafsīr Mà ba 'da al-țabì 'a I, 310,1-311,4 and 316,9) where Aristotle discusses how "that which is" ( $t o$ on $=a l$ huwiyya) and "that which is one" (to hen = al-wähid) can be seen to be extensionally identical but intensionally different, in the sense that both are equally predicable of substance (ousia). See also "That which is one' is said of [the same things] 'that which is' is said of" (to hen legetai hōsper kai to on = yuqūl al-wāhid ka-mițli mā tuqāl al-huwiyya ayḍan) at Metaph. 7.16, 1040b16-24 (= Tafsīr Mà ba'da al-țabì 'a II, 999,14-1000,5); and “'That which is' and 'that which is one' are the predicates spoken most universally of everything" (to gar on kai to hen katholou katēgoreitai malista pantōn = fa-inna al-wāḥid wa-al-huwiyya maqūlāt kulliyya aktar dōalika tuqūl 'alā ğamī' al-ašyō') at Metaph. 10.2, 1053b16-21 (= Tafsīr Mā ba'da al-țabí 'a III, 1268,11-1269,3).

${ }^{35}$ Kitāb al-nağāt, ed. M. Fakhry (Beirut, 1985), 245, 20-21. This passage is identical to Hikma 'Arüdiyya, MS Uppsala OR. 364, 2v8-10, but given how little we know about the Hikma 'Arüdiyya text, and given the many correspondences between it and the Nağa $\bar{t}$, it is impossible to say if the Nağăt passage is a copy of the very early Hikma 'Arüdiyya passage, or if what purports to be the Hikma 'Arüdiyya passage is merely a copy of the later Nağăt. Gutas discusses the Nağāt's correspondence to Avicenna's earliest works in Avicenna and the Aristotelian Tradition, 87-93 and 112-14. 
applies to any entity that the other does not apply to. Yet in Ilāhiyyāt 7.1 Avicenna implies that thing is a universally applicable subject of which one and existent may be predicated. In other words it is one and existent, not thing and existent, which are extensionally identical yet intensionally different. Thing therefore seems to be a category which is more basic, and hence logically prior, to the categories one and existent.

This logical priority is reinforced by Avicenna's implication in Ilāhiyyāt 5.1 that properly speaking, thing should be elevated above considerations of existence. There Avicenna claims that a universal is a thing when taken in itself, that is, when it is separated from any consideration of the mode of its existence: one or many, concrete or mental, potential or actual. Not only is a universal taken in itself a thing, but - we are told in Madhal 1.12 - a genus or a species taken in itself is a thing. Even more importantly, Avicenna says in the Nağāt passage that an essence taken in itself is a thing, and that "one" - and, by implication, "existent" - is merely a necessary accident of essence taken in itself. Most starkly of all, Avicenna asserts in Madhal 1.2 that an essence has a third aspect, unrelated to any type of existence whatsoever.

The clear message given in Ilāhiyyāt 1.5 that thing and existent are co-implied, with neither being prior to the other, is therefore muffled by the many hints from the other passages that thing is logically prior to existent. More serious is the question of extension. For while all the passages are consistent in maintaining that thing and existent have different meanings, two in particular - Nağàt/Ilāhiyyāt 1.9 and Madhal 1.2 - imply that there is a separate category of things - essence taken in itself - to which existence does not apply. In these passages Avicenna seems to have forced himself into advocating the $\mathrm{Mu}$ 'tazilite position that existent is subsumed extensionally but not intensionally under thing; that is, that existents are always things but things are not always existents. ${ }^{36}$

\footnotetext{
${ }^{36}$ Much ink has been spilled trying to determine how Avicenna meant this extra aspect of essence to be understood. Some maintain that it should be understood simply in the context of a thought experiment, in which mähiyya can be separated in a purely logical sense from its existence as a concrete individual in the outside world and from its existence as a universal concept in the mind. Others, citing remarks Avicenna makes in Ilāhiyyāt 5.2, believe that the passage provides evidence that Avicenna thought existence was attached to essence merely as an accident. Western interpreters in the Catholic tradition have generally understood Avicenna as implying the latter,
} 
Is there any other evidence in Avicenna's writings to help us understand his concept of thingness? Does that evidence allow us to reconcile Avicenna's various positions on things and essences? These questions will be addressed in Parts 2 and 3.

\section{PART 2: ŠAY'TYYA OR SABABIYYA?}

To get a fuller picture of the subtle tension in Avicenna's thought between things and essences we must look for other instances of šay'iyya in Avicenna's writings. After all, the isolated instance of thingness in Ilāhiyyāt 1.5 - the only instance of šay'iyya that Jolivet cites - hardly constitutes a fully articulated concept in Avicenna's thought. Where else, if anywhere, does šay'iyya appear in Avicenna's works? It turns out that the Ilāhiyyāt 1.5 passage, the one that so clearly echoes the earlier $\mathrm{Mu}$ 'tazilite discussions of things and existents, is not the only time when Avicenna uses the term šay'iyya .

Far more often than its lonely appearance there, where the mutakallimūn are hovering in the background, Avicenna uses šay'iyya in a cluster of discussions which have nothing to do with early kalām debates and which are driven by a problem specific to Aristotelian philosophy: the relation between efficient and final causes. In Ilāhiyyāt 6.5 Avicenna writes:

$(292,1)$ The subsequent objection [to the reality of final causation, viz., "How can the end be anything but posterior to the other causes?"] will be solved by knowing that the end may be taken to be a thing as well as taken to be an existent. Although a thing cannot be other than an existent, the difference between thing and existent is just like the difference between some entity and its concomitant (wa-al-farq bayna al-šay' wa-al-mawğūd wa-in kāna alšay' lā yakūn illā mawğūdan ka-al-farq bayna al-amr wa lāzimihi). You have

but consensus is now emerging that the former is also a feasible interpretation. For a sampling of different views see Goichon, La distinction de l'essence et de l'existence; É. Gilson, L'Être et l'essence (Paris, 1948), 121-31; F. Rahman, "Essence and existence in Avicenna," Mediaeval and Renaissance Studies, 4 (1958), 1-16; P. Morewedge, "Philosophical analysis of Ibn Sīnā's essence-existence distinction," JAOS, 92/3 (1972): 425-35; F. Rahman, "Essence and existence in Ibn Sīnā: the myth and the reality," Hamdard Islamicus, 4 (1981): 3-14; D. Burrell, "Essence and existence: Avicenna and Greek philosophy," MIDEO, 17 (1986): 53-66; S. H. Nasr, "Existence (wuğūd) and quiddity (māhiyyah) in Islamic philosophy," International Philosophical Quarterly, 29/4 (1989): 409-28; M. Marmura, "Quiddity and universality in Avicenna," in P. Morewedge (ed.), Neoplatonism and Islamic Thought (Albany, N.Y., 1992), 77-87. 
already come to know and to verify this. Consider, once again, the case of man: man has an inner reality, consisting of his definition and his essence, which is not conditioned upon [his] existence's being particular or general, concrete or in the soul, or potential or actual.

$(292,6)$ Each cause, insofar as it is that [particular] cause, has an inner reality and a thingness. In its thingness the final cause is the reason why the other causes actually exist as causes. In its existence the final cause is the effect of the other causes' actually [existing] as causes. It is as if the thingness of the final cause were the cause of the cause of its [own] existence; conversely it is as if its existence were the effect of the effect of its [own] thingness. However its thingness does not become a cause unless it occurs as an image formed in the soul, or as something analogous to that. The only cause of the final cause in its thingness is another cause which is different from the cause toward which one thing sets [another] in motion, or toward which something is set in motion.

Know that something can be caused in its thingness, and caused in its existence. An example of what is caused in its thingness is twoness: contained in the definition of its being twoness is its being caused by oneness. What is caused in its existence is clear, not unknown.

Similarly, one thing might possess another thing that occurs as an existent in its thingness, as twoness possesses numberness; or else one thing might be additional to another thing that is added to its thingness, as wood and stone contain rectilinearity. Natural bodies are causes of the thingness of many forms and accidents (I mean of those [forms and accidents] which can only recur in them), as well as being causes of the existence of some of them [the forms and accidents] without [being a cause of] their [the forms' and accidents'] thingness, as is sometimes thought to be the case in mathematics.

$(293,4)$ It has thus been easy for you to understand [sic!] that the final cause, with regard to its thingness, is prior to the efficient and receptive causes, and similarly, prior to form insofar as form is a formal cause leading toward it [the final cause]. In addition, the final cause is prior to the other causes in its existence in the soul. As for [the final cause's being prior to the other causes] in the agent's soul, this is because it [the final cause] comes to exist first and then agency, seeking out a receptive patient, and the quality of the form come to be represented as images. As for [the final cause's being prior to the other causes] in the souls of those other than the agent, one [cause] need not follow another in any kind of necessary order. Therefore, in terms of thingness and in terms of existence in the intellect, there is no cause prior to the final [cause]; instead, it is a cause of the rest of the causes' becoming causes. However, the actual existence of the other causes as causes is [itself] a cause of its [the final cause's] existence. The final cause is a cause not insofar as it is an existent, but insofar as it is a thing. In the sense that it is a cause, it is the cause of the causes, while in the other sense it is the effect of the causes.

$(293,12)$ This is [so] when the final cause comes about in [the world of] generation; when, however, the final cause does not exist in [the world of] generation, but its existence is more sublime than [that of the world of] generation 
(as will be explained in its place), then none of the other causes is a cause of it [the final cause], nor are they in the case of the One which is Itself occurrence and existence. [In this case] therefore the final cause is uncaused by the rest of the causes not because it is a final cause but rather because it [already] possesses being. [But] even if it did not have being it would still be completely uncaused. When you consider its [the final cause's] being a final cause, you will find it to be a cause of the rest of the causes' being causes (viz., being an efficient cause and a receptive cause and a formal cause) but not of their being entities and existents in themselves. So what is essential to the final cause insofar as it is a final cause is being a cause of the rest of the causes, while what is accidental to it (insofar as it [the final cause] is understood to be [actually] occurring in the world of generation) is being an effect in the world of generation. It has thus been made clear to you how something may be cause as well as effect, given that it is [both] an agent and an end, this being one of the Natural Philosophers' principles. ${ }^{37}$

\section{Avicenna also mentions thingness in the same context in Nağāt/ Ilāhiyyāt 1.11:}

In terms of coming into existence ( $f \grave{i} h u s \bar{u}_{\bar{u}} l$ al-wuğ $\bar{u} d$ ) the end is posterior to the effect, while it is prior to the rest of the causes in terms of thingness. It is clear that thingness is something other than existence in concrete reality

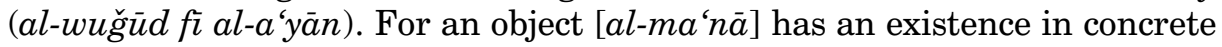
reality and an existence in the soul as well as something common [to both]: what is common [to both] is thingness. The final [cause] insofar as it is a thing is prior to the other causes and is the cause of the causes in terms of their being causes. Insofar as it is an existent in concrete reality it [the final cause] is posterior. When the efficient cause is not itself the final cause, the agent is posterior to the end in terms of thingness. This is because the other causes only become actual causes on account of the final. ${ }^{38}$

Before I try in Part 3 to explain what Avicenna means when he uses šay'iyya in these passages, and to determine whether or not this helps us reconcile the apparent tension in his thought

\footnotetext{
${ }^{37}$ Ilāhiyyāt, 292,6-294,5.

${ }^{38}$ Nağât/Ilāhiyyāt 1.11, 248,8-15; šay'iyya occurs on 248,9.10.11.14. As mentioned above, Gutas discusses the correspondence of the Nağăt to the Hikma 'Arüdiyya, Avicenna's earliest summa, in his Avicenna and the Aristotelian Tradition, 87-93 and 112-14. But unlike surrounding sections of the Nağàt, the discussion of causes is not identical to the analogous section in the Hikma 'Arüdiyya. In the earlier work, under the heading of al-mabda' ("origin"), Avicenna devotes only a very brief section to the causes, in which he combines and summarizes Aristotle's discussions in Metaph. 5.1 (on $a r k h \bar{e}$ ) and 5.2 (on aition). The efficient and final causes are called sababāni mufäriqanni (the two causes extrinsic to the effect), as opposed to the material and formal causes, which are called sababāni muqärināni (the two causes intrinsic to the effect). But there is no mention of how the efficient and final causes relate to each other: Hikma 'Arüdiyya, 4v16-5r5.
} 
between thingness and essence, I must devote Part 2 to resolving a textual problem. The problem is that there are some indications that sababiyya, "causality," and not šay'iyya, "thingness," was the word Avicenna used in the passages above. This is in spite of the overwhelming evidence provided by the manuscripts used to come up with the Cairo edition of the Ilähiyyāt, which are unanimous in their reading of šay'iyya. ${ }^{39} \mathrm{I}$ shall argue that the balance of evidence compels us to retain šay'iyya.

The textual problem in the Ilāhiyyāt might never have come to light had it not been for the fact that the Latin translator Gundisallinus consistently rendered what appears as šay'iyya in the Ilāhiyyāt 6.5 passage not as realitas or entitas, as one would have expected, but as causalitas. ${ }^{40}$ For example, the Ilāhiyyāt 6.5 assertion that "Each cause, insofar as it is that [particular] cause, has an inner reality and a thingness," and which reads in Arabic:

wa-kullu 'illatin fa-innahā min hayțu hiya tilka al-'illatu lahā haqīqatun wa-šay'iyyatun

was rendered into Latin as:

omnis autem causa, inquantum est ipsa causa, habet certitudine et causalitatem. ${ }^{41}$

One explanation of this anomaly takes into account the fact that translating Avicenna's philosophical works into Latin appears to have been a two-step process. A first translator - the Jewish émigré Ibn Dāwūd, or Avendauth - would render the Arabic orally into the vernacular Spanish of twelfth-century Toledo; as he went along, a second translator - the Catholic cleric Gundissalinus would render the vernacular Spanish into proper philosophical Latin. ${ }^{42}$ Given this scenario, it is easy to imagine how the first

${ }^{39}$ The manuscripts examined for the Cairo edition are described in the introduction to G. Anawati's French translation of the Ilāhiyyāt (Avicenne: La Métaphysique $d u$ Shifā' [Paris, 1978], 17-21). The use of šay'iyya in the Nağàt is confirmed in the Renaissance edition: Kitāb al-nă̌ăt muhtașar al-šifā' li-ibn Sīnā (Rome, 1593), $58,22-26$.

${ }^{40}$ Ed. S. van Riet, Avicenna Latinus: Liber de philosophia prima sive scientia divina $V$-X (Leiden, 1980), 337,88.90.91.92.94.96.97.00.1.3.5 and 338,11 (= Ilāhiyyāt, 292,6 bis.8.9 bis.10.12.14.16 and 293,2.3.4.8). On the translators, see ed. S. van Riet, Avicenna Latinus: Liber de philosophia prima sive scientia divina I-IV (Leiden, 1977), 123*.

${ }^{41}$ Liber de philosophia prima $V-X, 336,87-337,88$ (= Ilāhiyyāt, 292,6).

${ }^{42}$ Ed. S. van Riet, Avicenna Latinus: Liber de anima seu sextus de naturalibus I-III (Leiden, 1972), 95*-98* and C. Burnett, The Coherence of the Arabic-Latin Translation Programme in Toledo in the Twelfth Century (Berlin, 1997), 12-14. 
translator might have tried faithfully to render šay'iyya into the vernacular Spanish as cosità. The second translator might then have confused cosità, "thingness," with causità, "causality," terms which were probably pronounced much the same. ${ }^{43}$

It appears more likely, however, that tașhïf, a scribal misplacement of diacritical marks, was the cause of the divergence between the Arabic and Latin texts. The tashif in this case would consist of a scribe's having mispointed say'iyya as sababiyya ("causality"), a far less mysterious term (I take it as obvious that šay'iyya is the lectio difficilior here). Confusing the pairs of terms is perfectly understandable. For in a medieval Arabic manuscript, many of whose words would have been without diacritical marks, the skeleton (rasm) سسه is just as easily pointed as سببية as it is as شيئية. But given the lack of extant Arabic Ilāhiyyāt manuscripts from before 1284 (let alone from before the Arabic-Latin translation movement in the middle of the twelfth century), it is impossible to say whether a scribe mistranscribed šay'iyya as sababiyya before the manuscript reached Avendauth's hands and Avendauth then read the mispointed manuscript accurately; whether the manuscript reached Avendauth with these words pointed as šay'iyya and he then "corrected" the pointing to sababiyya before translating it; or whether the manuscript reached Avendauth with these words unpointed and he then pointed them incorrectly as sababiyya before translating them.

In any case, what inclines me towards attributing the divergence between the Arabic and Latin texts to tashif if and not to mishearing is that what appears as šay'iyya in the Ilāhiyyāt 1.5 passage discussed earlier was also incorrectly rendered into Latin but this time as similitudinem, clearly the result of Avendauth's (or an earlier scribe's) mispointing ( been pointed as تشبيه instead of شيئية or Her than of Gundissalinus' mishearing. ${ }^{44}$

\footnotetext{
${ }^{43}$ This is the theory advanced by d'Alverny with regard to two instances where, as she understood it, cosà had been misunderstood as causa. These are mentioned (without references to the text) in M.T. d'Alverny, "L'introduction d'Avicenne en Occident," Revue du Caire, 14/141 (1951): 130-9, at 133, and repeated in her "Les traductions latines d'Ibn Sina et leur diffusion au Moyen Age," Millénaire d'Avicenne (Cairo, 1952), 59-69, at 60. The instances of mistranslation she probably had in mind are S. van Riet (ed.), Avicenna Latinus: Liber de anima seu sextus de naturalibus IIII, 192,20 (= Avicenna's De Anima - Arabic Text, ed. F. Rahman [Oxford, 1959], 103,11) and 273,11 (= Avicenna's De Anima - Arabic Text, 154,19).

${ }^{44}$ Liber de philosophia prima sive scientia divina I-IV, 38,21 (= Ilāhiyyāt, 33,17). Jolivet seems not to have noticed this mistranslation; Fazlur Rahman mentions it in
} 
On the other hand, the specter of tașif if raises the chilling possibility that the original Arabic texts - the ones written or dictated by Avicenna himself - should in fact be read with sababiyya, not šay'iyya. This concern is heightened by the fact that the oldest manuscript of the Latin translation of the Ilāhiyyāt dates from about 1240, while the oldest Arabic manuscript of the Ilāhiyyāt dates from $1284 .{ }^{45}$ However, I believe that the Latin translation does not, in itself, provide enough evidence to justify concluding that Avicenna wrote or dictated sababiyya rather than šay'iyya. First of all, if causalitas were an indication that the original Arabic should read sababiyya, not šay'iyya, then - by way of consistency - we would also expect to see the instances of šay' in the Ilāhiyyāt 6.5 passage to have been rendered into Latin as causa. This is not the case. The Arabic of the Ilāhiyyāt 6.5 passage immediately preceding the last quotation:

wa-ammā al-šakku allad̄i yalīhi fa-yanḥallu bi-an yu'lama anna al-ġàyata tufraḍ šay'an wa-tufraḍu mawğūdan

was rendered accurately into Latin as:

Sed dubitatio quae sequitur hic solvitur hoc modo: scilicet, iam scis quod finis ponitur res et ponitur ens. ${ }^{46}$

Second, sabab would clearly have been out of place in almost every instance where šay' was mistranslated into Latin as causa rather than res, so we can be quite certain that in Ilähiyyāt 6.5, at least, the original Arabic text did not read sabab. ${ }^{47}$

his "Essence and existence in Avicenna," 5 (fn. 2), as does M. Khodeiri, "Lexique arabo-latin de la Métaphysique du Shifā'," MIDEO, 6 (1959-61): 309-24 at 316. Van Riet reckons similitudinem derives from šabìha, although in my opinion tašbīh is just as easy to impute from the skeleton. Elsewhere in the Latin translation of the Ilāhiyyāt, bi-sababihi was mistranslated as comparationis - van Riet sees this as a result of misunderstanding it as nisbatahu: 188,80 (= Ilāhiyyāt, 166,4) - and sababun as comparationes: 493,96 (= Ilāhiyyāt, 413,12). This confusion also occurs in a passage of the $F \bar{\imath}$ al-nafs, where sabab was translated into Latin as comparatio (ed. S. van Riet, Avicenna Latinus: Liber de anima seu sextus de naturalibus IV-V [Leiden, 1968], 20,79 = Avicenna's De Anima - Arabic Text, 174,14).

${ }^{45}$ Liber de philosophia prima sive scientia divina I-IV, 125*-138*.

${ }^{46}$ Liber de philosophia prima V-X, 336,84-85 (= Ilāhiyyāt, 292,1).

${ }^{47} \mathrm{In}$ addition to the two instances alluded to by d'Alverny, šay' is mistranslated as causa elsewhere in the Latin version of the Ilāhiyyāt: šay'ayni becomes duarum causarum at 99,62 (= Ilāhiyyāt, 86,3), and sā'ir al-ašy $\bar{a}$ ' becomes ceterae causae at 394,84 (= Ilāhiyyāt, 341,3). In the Latin translation of al-Af'āl wa al-infi ‘ālàt, the fourth book of the Țabi 'iyyāt, šay' was also occasionally mistranslated as causa: ed. S. van Riet, Avicenna Latinus: Liber quartus naturalium de actionibus et passionibus 
All in all, the evidence provided by the Latin translation of the Ilähiyyāt (and the parallels in the translation of the $F \bar{\imath}$ alnafs) allows us merely to hypothesize that tashif occurred in one or more of the manuscript lines that reached Andalusia. It is not conclusive with regard to the question of whether the original text should read sababiyya rather than šay'iyya.

The Latin mistranslation of šay'iyya in the Ilāhiyyāt - if it was in fact a mistranslation, as I believe - does seem to explain the absence of analogous concepts in discussions of final and efficient causes by later Latin philosophers, and the presence in those same discussions of causalitas. ${ }^{48}$ Medieval European

qualitatum primarum (Leiden, 1989), 23,72 (= Kitāàb al-šifā': al-Ṭabī'iyyāt (4)/ al$A f^{\prime} \bar{a} l$ wa al-infi'ālāt, ed. M. Qāsim [Cairo, 1965], 213,15); 28,54 (=al-Af'āl wa alinfi'ālāt, 217,3); and 79,73 (= al-Af'âl wa al-infi' $\left.{ }^{\prime} \bar{a} l \bar{a} t, 256,6\right)$. Conversely, asbāb was mistranslated in the $F \bar{\imath}$ al-nafs as rebus at 21,82 (= Avicenna's De Anima - Arabic Text, 174,15), and sabab as res at 21,83 (= Avicenna's De Anima - Arabic Text, 174,16).

${ }^{48}$ The Latin Avicenna's "theory" that the final cause is prior to the efficient in terms of causality is cited explicitly by Henry of Ghent (d. 1293), Quodlibet XIII, ed. J. Decorte (Leuven, 1985), 106,71-78; and by Duns Scotus (d. 1308), Quaestiones super libros Metaphysicorum Aristotelis I-IX, Bk. 5, Quest. 1, Para. 51. Avicenna's "theory" (or the gloss on it contained in the Latin translation of Gazālī's Maqāṣid see note 51) also seems to inform the opinions of Alexander of Hales (d. 1245), In duodecim Aristotelis Metaphysicae libros (Venice, 1572): in Metaph. 1, 12rC (Avicenna's Ilāhiyyāt 6 is mentioned at $12 \mathrm{vE}$ and 104rD), in Metaph. 3, 54rD-55rD, and in Metaph. 5, 105rA-D; of Thomas Aquinas (d. 1274), Scriptum super libros Sententiarum 1.8 (= E.M. Macierowski (ed. and trans.), Thomas Aquinas's Earliest Treatment of the Divine Essence [Binghamton, N.Y., 1998], 52,5-6); in Metaph. 5 \#775 and \#782; in Phys. 2.3, \#186; Summa contra gentiles 3.17.9; of Siger of Brabant (d. 1283), Quaestiones in metaphysicam 5.9 (Cambridge MS), ed. A. Maurer 3-28 (Louvain, 1983), 203-4; of John Buridan (d. 1358), in Metaph. 5, quaest. 1, fols 26a-27a; of Albert of Saxony (d. 1390), Expositio et quaestiones in Aristotelis Physicam ad Albertum de Saxonia attributae I, ed. B. Patar (Louvain, 1999), 111,6-9; and of Francisco Suarez (d. 1617), Disputationes metaphysicae Disp. XXVII, Sect. 2, paras 7-14, (= Dispitaciones metafisicas IV, eds and trans. S. Rabade Romeo, S. Caballero Sanchez and A. Puigcerver Zanon [Madrid, 1962], 172-77). A. Maier ("Finalkausalität und Naturgesetz," in her Metaphysische Hintergründe der spätscholastischen Naturphilosophie [Rome, 1955], 273-335 at 212-13 and 302-3) discusses Avicenna's "theory" and relates it to Buridan's; see also J. Biard, "Le système des causes dans la philosophie naturelle de Jean Buridan," in A. Hasnawi et al. (eds), Perspectives arabes et médiévales sur la tradition scientifique et philosophique grecque (Paris, 1997), 491-504 at 494-5. This is not to say that Avicenna's concept of thingness was lost forever to European thinkers. In 1907 Horten translated the instances of šay'iyya in Ilāhiyyāt 6.5 correctly into German as Dingheit (M. Horten [trans.], Die Metaphysik Avicennas [Halle, 1907], 428-9), and the instances of šay'iyya in the Nağàt passage were translated by Carame into Latin as entitas: N. Carame (trans.), Avicennae metaphysices compendium [Rome, 1926], 34,21-35,19 (šay'iyya is rendered as entitas at 34,23 bis and $35,2.7)$. 
thinkers would probably not have been struck to find Avicenna's concept of thingness missing from their translations of the Ilāhiyyāt, since šay'iyya does not appear in Gazālì's summary of Islamic philosophy, the Maqāșid al-falāsifa, through which - as Intentiones philosophorum - many Latins were introduced to Avicenna's thought. The Maqāsid was popular due to Gazālī's fluency of style and liberality with examples, qualities which Avicenna painfully lacked. It is an irony of the history of medieval philosophy that during the period before Averroes' Tahāfut al-tahāfut was translated into Latin - that is, before Gazālī was exposed as a philosophy-hater - "Algazel" was seen by some Europeans as Avicenna's greatest disciple. ${ }^{49}$

The non-appearance of šay'iyya in the Maqāșid is, on the surface, evidence inclining us towards thinking that the Ilāhiyyāt 6.5 and Nağàt passages should be emended to read sababiyya. But šay'iyya's absence in the Maqāsid has a more straightforward explanation. Gazālī based the Maqāṣid primarily (though not entirely) on Avicenna's Persian summa, the Dānišnāma-yi 'Alā' '̄, in which a Persianized equivalent of šay'iyya does not make an appearance. Avicenna's Persian statements in the Dānišnāma that:

The end is the cause of all the causes... So when there is an end, it is the cause of all the causes ${ }^{50}$

were rendered into Arabic by Gazālī in the Maqāṣid as:

Part of what is special about the final cause is the fact that the other causes become causes through it... So when the final exists among all the causes, it is the cause of the causes. ${ }^{51}$

${ }^{49}$ e.g. Giles of Rome, introducing the section on al-Gazāli from his Errors of the Philosophers: Algazel autem, ut plurimum Avicennam sequens et eius abbreviator existens...: Giles of Rome Errores Philosophorum, ed. J. Koch (Milwaukee, 1944), 38,4-5.

${ }^{50}$ Ilāhiyyāt-i Dānišnāma-yi 'Alā' '̄, ed. M. Mu'īn (Tehran, 1952), 54,9-10 and 55,2.

${ }^{51}$ Maqūṣid al-falāsifa, ed. S. Dunyā (Cairo, 1961), 190,10.13. Interestingly, the Intentiones philosophorum - the Latin translation of the Maquașid al falāsifa - contains several extra lines which are in neither the Dānišnāma nor the Arabic edition of the Maqāsid; these include the assertion "Indeed, the final cause is last in terms of existence, yet first and foremost in terms of intention" (Causa vero finalis est ultima in esse, et est prima et precedens in intencione = Algazel's Metaphysics, ed. J. Muckle [Toronto, 1933], 38,5-6). My guess is that the extra line is a gloss by Avendauth or Gundissalinus, given their intimate involvement in translating both Gazālī's Maqūṣid and Avicenna's Ilāhiyyāt into Latin. S. Stern describes how this precept was applied to the arrangement of topics in philosophy books, in his "The first in thought is the last in action': The history of a saying attributed to Aristotle," Journal of Semitic Studies, 7/2 (1962): 234-52. 
Since Gazāli did not allow the straw-man philosopher of the Maqāsid to apply the concept of šay'iyya to the question of how efficient and final causes relate to each other, he probably felt no need to criticize thingness in the polemical Tahāfut al-falāsifa. And perhaps as a consequence of šay'iyya's absence in the Tahāfut al-falāsifa, Averroes may have felt no need to raise the topic in the Tahāfut at-tahäfut. Nor is Avicenna's distinction between thingness and existence cited by Averroes in the latter's long commentaries on any of the most canonical Aristotelian discussions of the four causes, Physics 2.3 and 2.7 and Metaphysics 5.1 and 5.2. ${ }^{52}$ Therefore, šay'iyya's absence from Gazālì's (and hence Averroes') discussions of efficient and final causes does not by itself constitute evidence in favor of either reading.

Some evidence that appears to favor sababiyya may be found in the writings of two other thinkers trained in the Aš'arite theological tradition. The Aš‘arite mutakallimūn al-Šahrastānī and Fah̆r al-Dīn al-Rāzì wrote extensively about Avicenna's metaphysics, among other topics. If šay'iyya were to appear in one of their summaries or critiques of Avicenna's discussions of causality, it might help confirm its inclusion in the Ilāhiyyāt 6.5 and Nağ $\bar{a} t$ passages. The opposite seems at first glance to be the case. One major piece of evidence tempting us to reject šay'iyya in favor of sababiyya in the Nağàt is the fact that in Šahrastānī's doxography, the Kitāb al-milal wa al-nihal, Šahrastānī paraphrases the Nağàt passage on final and efficient causes but appears to read sababiyya instead of šay'iyya. According to the editor's critical apparatus, however, most of the Milal manuscripts read šay'iyya. The Milal's importance as a piece of evidence one way or the other is therefore limited..$^{53}$

More alarming is the evidence pointed to by Rāzì. Rāzì himself wrote a very important commentary on as well as a shorter summary of Avicenna's Kitāb al-išārāt wa al-tanbīhāt, a late work of Avicenna that greatly influenced subsequent Islamic philosophy. ${ }^{54}$ In the Išarāt discussions of final and efficient causes šay'iyya does not make an appearance. Instead, Avicenna uses māhiyya - not šay'iyya - in the passage from the Išārāt's

\footnotetext{
${ }^{52}$ Averroes in Phys. 2.3 and 2.7 (= Aristotelis opera cum Averois commentariis IV [Venice, 1562-1574], 59D-63K) and Averroes in Metaph. 5.1 and 5.2 (= Tafsìr Mà $b a^{\prime} d a$ al-țabī'a II, ed. M. Bouyges [Beirut, 1942], 475,1-481,8; 483,7-487,8; 490,1497,6).

${ }^{53}$ Kitāb al-milal wa al-niḥal II, ed. M. Badrān (Cairo, no date), 1092,6-1093,4.

${ }^{54}$ In Part 3 I briefly discuss Michot's objections to giving the Išàrāt a late date.
} 
metaphysics section (Namat 4: Fì al-wuğūd wa-ilalihi) which parallels the Ilāhiyyāt 6.5 and Nağàt passages, as well as the term 'illiyya (causality):

Something may be caused with reference to its essence and its inner reality, and it may be caused in terms of its existence... The final... is the efficient cause of the causality ['illiyya] of the efficient cause. ${ }^{55}$

In another passage from Išàrāt 4, Avicenna says:

The final cause - that on account of which the thing is - is a cause, through its essence [bi-māhiyyatihi] and its [being an] object (wa-ma'nāhu), of the causality ['illiyya] of the efficient cause, while it is an effect of it in its existence. The efficient cause is a cause of its [the end's] existence if it is one of the ends that actually come into being, but it [the efficient cause] is not a cause of its [the end's] causality nor of its [being an] object. ${ }^{56}$

In his summary of the Išàrāt, entitled Lubāb al-išàrāt, Rāzì has this to say about the Išàrāt passages:

How clever the Shaykh was to say that the final cause is an efficient cause of the causality ['illiyya] of the efficient cause..$^{57}$

Now to my mind Avicenna's use of 'illiyya in the Išàrāt passages devoted to efficient and final causality is simply evidence of what appears to be an almost universal preference for 'illiyya over sababiyya in his works. ${ }^{58}$ But a counterargument might run like this. Given šay'iyya's absence in the Išărāt passages, and given instances elsewhere in Avicenna's works where he uses 'illiyya to describe priority in causality, we would be perfectly justified in emending the Ilāhiyyāt 6.5 and Nağàt passages to read sababiyya instead of šay'iyya. ${ }^{59}$ In other words, Avicenna sometimes uses

${ }^{55}$ Kitāb al-išārāt wa al-tanbīhāt, ed. J. Forget (= Ibn Sīnā: Le Livre des théorèmes et des avertissements), (Leiden, 1892), 139,14-20.

${ }^{56}$ Kitāb al-išārāt wa al-tanbīhāt, 140,6-9.

${ }^{57} \mathrm{Kit} \bar{a} b$ lubāb al-išāāàt, ed. 'A.S. 'Atịahah (Cairo, 1936), 80,4-5. Rāzī echoes this in his fully fledged commentary, Šarh al-išārāt (= Śarhay al-išāāàt, no ed. [Qum, 1983 or 1984], 193,36-194,20) and in his Mabāhhiț mašriqiyya (al-Mabāḥit al-mašriqiyya I, ed. M. al-Bag̀dādī [Beirut, 1990], 661,21-662,8).

${ }^{58}$ e.g. Ilāhiyyāt 16,$3 ; 166,12 ; 169,10$ bis; and 266,11 . The only instance of sababiyya I have come across in Avicenna's works is in his 'Uyün al-hikma (= Avicennae Fontes sapientiae, ed. 'A. Badawī [Cairo, 1954], 52,8). According to the editor's apparatus, however, the manuscripts contain many variant readings of sababiyya, and in any case, the term is not applied there specifically to the final cause but to the substrate $\left(m a w d \bar{u}^{\circ}\right)$, end and agent collectively.

${ }^{59}$ See aqdam bi al-illiyya in Hikma 'Arüdiyya, 5v4 and 83v15, and in Kitāb alšifā'/Manțiq (5): al-Burhān, ed. A. 'Afîfì (Cairo, 1956), 297,10-11; taqaddum fì al'illiyya in Avicenna's De Anima - Arabic Text, 230,3, and in Kitāb al-hidàya, ed. M. 'Abduh (Cairo, 1974), 241,1; and qabla fi al-'illiyya in Hikma 'Arüdìyya, 5r13. 
'illiyya to describe priority in causality, and other times (e.g. in the Ilāhiyyāt 6.5 and Nağàt passages) uses sababiyya to describe priority in causality; šay'iyya need not come into the picture at all.

As attractive as this counterargument might appear, I believe it suffers from flaws graver than those of my own argument. First of all, when Avicenna talks about priority in 'illiyya it is clear from the contexts in which the term appears that he is referring to the priority enjoyed by any cause - be it formal, material, final or efficient - to its effect. As far as I know, Avicenna nowhere says that the final cause in particular enjoys priority in 'illiyya to the efficient cause. Second, Avicenna's assertion in the Išārāt that the final cause is a cause through its essence (bi-māhiyyatihā) of the causality of the efficient cause (li-'illiyyat al-'illa al-fá 'iliyya) is perfectly reconcilable with his assertions in Ilāhiyyāt 6.5 that the final cause is both a cause through its own thingness and of the efficient cause's thingness. As for the first prepositional phrase, the Išàrāt passages are meant to show that the final cause's priority derives from its essence; and essence, as I have shown in Part 1 , is conceptually very similar, though apparently not identical, to thingness. Because māhiyya is much closer in meaning to šay'iyya than it is to sababiyya, the Išârāt passages can just as easily be understood as providing evidence in favor of, rather than against, retaining šay'iyya in the Nağàt and Ilāhiyyat 6.5 passages. As for the second prepositional phrase, the apparent discrepancy between the final cause's being the cause of the efficient cause's šay'iyya or of its 'illiyya, is solved by recognizing the simple fact that a cause's šay'iyya is precisely its 'illiyya.

My confidence in šay'iyya is strengthened by turning from the evidence in later Aš'arism to that in later Shi'ite Avicennism. For example, in Tūsī's commentary on the Išārāt passages on final and efficient causes, he follows Avicenna's lead and uses māhiyya as well as 'illiyya:

The essence of the end and its [being an] object - I mean its being some thing or other (kawnahā šay'an $m \bar{a})$ - is different from its existence... [The final cause's] causality ('illiyyatuhā) consists of the fact that it makes the agent an actual agent and is thus a cause of the agency of the agent. The agent is a cause of the fact that that essence [of the final cause] becomes an existent. Thus the essence of the end is a cause of the cause of its existence not in an absolute sense, but in a certain respect, so no circularity need be implied by this. ${ }^{60}$

${ }^{60}$ Țūsī, Šarh al-išārāt, 193,31-194,6. Compare similar uses of māhiyya by Avicenna's pupil Bahmanyār ibn al-Marzubān (al-Taḥṣīl, ed. M. Muṭahharī [Tehran, 
It seems clear from his gloss on māhiyya and ma'na - that they refer to the end's being some thing or other - that TTusì had read the Ilāhiyyāt 6.5 and Nağàt passages carefully and was borrowing from them to flesh out the much terser Išărāt passage. For it is the distinction between essence and existence, not one between causality and existence, that TTūsī (rightly) sees as underlying Avicenna's distinction between the final cause's causality from the efficient cause's causality.

Like Ṭùsī, Mullā Șadrā - in his commentary on the Ilāhiyyāt 6.5 passage - seems aware of the Išârāt passage when he pairs šay'iyya with māhiyya, and uses 'illiyya:

Therefore the final cause, through its essence and its thingness, is a cause of the causality of the rest of the causes [li-'illiyya sā'ir al-'ilal]. ${ }^{61}$

Even in his own philosophical treatises Mullā Șadrā occasionally retains šay'iyya. In the Kitāb al-asfār, for example, he says:

Although with respect to thingness (šay'iyya) the end is prior to the act, it follows nonetheless that with respect to existence it is posterior to the act and subsequent to it (mutarattiba 'alayhā). ${ }^{62}$

To summarize Part 2, then, pieces of evidence from the later Latin and Aš'arite traditions tempt us to reject šay'iyya and replace it with sababiyya. Nevertheless, I feel the burden of proof still lies with anyone who would advocate such an emendation, in view of the following factors: the apparent unanimity of the extant Nağàt and Ilāhiyyāt manuscripts in reading šay'iyya; the inconsistent and scattered mistranslations of $s a b a b, s ̌ a y$ ' and tašbìh in the Latin translations of the Ilähiyyāt and the $F \bar{\imath}$ al-nafs, which indicate taṣhiff in the Latin translators' Arabic manuscripts but not necessarily in the originals those manuscripts were derived from; Avicenna's use of máhiyya - a term that is far closer in meaning to šay'iyya than sababiyya - in the parallel Išàrāt passages; Avicenna's apparent preference for 'illiyya over sababiyya when discussing causality;

1997], 546,1-9), as well as Sabzawārī (d. 1878) (Šarh ğurar al-farā'id (also known as Šarḥ-i manzūmah), ed. M. Muhaqqiq and T. Izutsu [Tehran, 1969], 161,11-12).

${ }^{61}$ Al-Ta 'lìqqàt 'alā ilāhiyyāt al-šifō', in Avicenna, al-Šifá' II (Tehran, 1886), 258,3. In his Kitāb al-mašà 'ir (= Le Livre des Pénétrations métaphysiques, ed. H. Corbin [Paris/Tehran, 1964], 7,13 and 20,19.20) Mullā Șadrā - in existentialist rather than commentator mode - chucks šay'iyya into the dustbin of terms denoting essence.

${ }^{62}$ Al-Asfār al-arba'a II, ed. H.H. al-Āmulì (Tehran, 1995), 347,4-5. 
šay'iyya's appearance in Avicenna's Ta 'līqāt and Mubāhatâât, as we shall see in Part 3; Mullā Șadrā's equation of šay'iyya and māhiyya; and finally the principle of lectio difficilior, which clearly favors thingness over causality.

\section{PART 3: FROM PRIORITY IN ŠAY'TYYA TO PRIORITY IN MĀHIYYA}

Now that I have argued in favor of retaining thingness in Ilāhiyyāt 6.5 and Nağàt/Hikma Ilāhiyya 1.11, albeit with a few qualms, I must try to explain what exactly the term means in the context of Avicenna's discussion of the relation between efficient and final causes. Once this is done it will be easier to determine how these discussions contribute to our understanding of Avicenna's concepts of thingness and essence, and of his progression from the kalām problematic of šay' v. mawğùd to his own problematic of māhiyya v. wuğūd.

I think that when Avicenna asserts in Ilähiyyāt 6.5 that the final cause is prior in its šay'iyya to the efficient cause, he is using the term in one of the two early kaläm senses of thing: the notion that a thing (for example, the Day of Resurrection, or my great-great-granddaughter) can subsist mentally in God's - or anyone's - mind, before it exists in the real world. Here is an example of how thingness thus conceived works in final causation. I am thirsty and a bottle of soda is in the refrigerator. I want to quench my thirst by drinking that bottle of soda. Quenching my thirst exists in my mind as a final cause. My motion to the refrigerator - the efficient cause of my quenching my thirst - then comes into concrete existence in the outside world. But the quenching existed first in my mind - as a thing before it existed concretely in the outside world. In this sense the final cause is prior in its thingness (prior as a thing, that is) to the efficient cause. This is why Avicenna asserts in Ilāhiyyāt 6.5 that "its [i.e. the final cause's] thingness does not become a cause unless it occurs as an image formed in the soul" $(292,9)$ and "In terms of thingness and in terms of existence in the intellect, there is no cause prior to the final cause" (293,8-9). Avicenna's assertions are echoed in the Ta'līqàt:

The end is prior in its thingness to all the causes and posterior in the existence it derives from them. The end which is absolutely non-existent ( $a l$ - 
ġàya al-ma'dūma 'alā al-ițlāq) is not a cause. Instead, it must exist in the mind of the agent in order to perform its action. ${ }^{63}$

When šay'iyya is used in this way, as the basis for the priority enjoyed by things which are in the mind but which have not yet come into being in the outside world, it helps Avicenna flesh out an Aristotelian assertion: that the efficient and final causes can be seen to be causes of each other. In Physics 2.3 Aristotle briefly discusses the reciprocity between efficient and final causes:

Sometimes things are causes one of the other (esti de tina kai allèlōn aitia $=$ wa-qad takūnu ašyō'u ba'duhā sababun li-ba 'dihā). For example, hard work is the cause of the body's well-being and the body's well-being is the cause of hard work, though not in an identical way (all' ou ton auton tropon = gayra anna dālika laysa min wağhin wähidin); the body's well-being is a cause in that it is an intended end, while hard work is a cause in that it is the origin of motion. ${ }^{64}$

The challenge facing Avicenna here was to uphold Aristotle's relatively straightforward idea - that the efficient can be seen as the cause of the final and the final can be seen as the cause of the efficient - without falling into the trap of circularity. For if the final cause is simply the cause of the efficient cause, and the efficient is simply the cause of the final, each will be the cause of the cause of itself, and circularity will result. Avicenna had to find some way defend Aristotle's assertion by providing a metaphysical basis for the distinction between the ways in which the final cause and the efficient cause operate.

This is where the kalām distinction between šay' and mawğūd came in handy. Understood as a thing, the final cause can have a šay'iyya in the mind before it comes into existence concretely in the outside world. In terms of its being a šay' in the mind - in terms of its šay'iyya, that is - the final cause can be seen to be the cause of the efficient cause. On the other hand, the efficient cause comes into concrete existence in the outside world before the final cause comes into concrete existence in the outside world. My motion to the refrigerator exists concretely before my quenching exists concretely. By distinguishing between the final

${ }^{63}$ Ed. 'A. Badawī, al-Ta 'līqāt (Cairo, 1973), 128,17-19; also see 158,14.

${ }^{64}$ Phys. 2.3, 195a9-12 (= Arisțūtâlīs: al-Ṭabí'a 1, ed. 'A. Badawì [Cairo, 1964], 103,8-13). This is echoed in Metaph. 5.2, 1013b9-12 (= Mà ba'da al-tabī'a II, 486,910). In Metaph. 1.3, 983a32, Aristotle asserts that the final cause is the "opposite" (antikeimenē) of the efficient. 
cause's priority as thing and the efficient cause's priority as concrete existent, Avicenna has managed to wriggle out of the hole of circularity.

But while Avicenna's analysis in Ilähiyyāt 6.5 helps him flesh out Aristotle's assertion about the reciprocity between efficient and final causes, it raises two serious problems. The first is this: Let us assume, as Avicenna says, that all final causes are prior in their thingness to the efficient causes with which they are paired. It follows that nothing without priority in thingness will be a final cause; in other words, being prior in thingness will be a necessary condition of being a final cause. But this description of how the final cause works will exclude all natural phenomena from the domain of entities that occur for a final cause. This is because natural things - a tree, or a rock - possess no mind or consciousness in which the šay'iyya of an intended end can subsist before it exists in the outside world as a concrete existent. Thus natural processes - a tree's growth, or a rock's fall to the ground - will not operate according to final causation, and final causation will be restricted to intentional acts. ${ }^{65}$

Avicenna appears to be aware of the problematic implications of using šay'iyya as the basis on which the priority of the final cause rests when he appeals - again in his Ta 'lìqāt - to another Aristotelian assertion: that form and end are often identical, particularly in natural phenomena. ${ }^{66}$ In other words, simply completing the natural process by which a form inheres in a properly disposed matter can itself be regarded as a final cause, with the result that there is no need to appeal to intentionality or consciousness:

The form is sometimes the same as the end, as in the case of health: it is a form and it is the same as the end. The ends of natural entities are the same as the existence of the form in the matter, because an individual nature will move only in order for a form to inhere in a matter. ${ }^{67}$

${ }^{65}$ For an example of this line of argument see Rāzì, Šarh al-išārāt, 194,1-6.

${ }^{66}$ Phys. 2.7, 198a25 (= Tabī'a 137,20-138,1) and 198b3 (= Tabī'a 140,12-13); Metaph. 5.24, 1023a34 (= Tafsìr mà ba'da al-țabí $a$ II 655,9-10) and 8.4, 1044a36-b1 (= Tafsīr mā ba'da al-tabì 'a II 1074,1-2); and GC 1.7, 324b13-18. Following Aristotle and his commentators, Avicenna uses the notion of perfection (entelekheia $=$ kamāl and tamām) to link the intrinsic causality of the form and the extrinsic causality of the end; on this see my "Avicenna on perfection and the perfect," in R. Wisnovsky (ed.), Aspects of Avicenna, Princeton Papers: Interdisciplinary Journal of Middle Eastern Studies, forthcoming.

${ }^{67}$ Al-Ta'lìqāt, 128,17-25. 
But why has Avicenna not felt free to restrict the final cause to intentional action and be done with it? Apart from violating a fundamental Aristotelian belief in natural teleology, restricting the final cause's causality to intentional action would also undermine almost universal Peripatetic assertions of the priority of the science of final causality. Aristotle is clear in holding that knowledge of the final cause is superior to that of the other causes. ${ }^{68}$ Following him, Avicenna not only says that knowledge of the final cause is the most excellent part of metaphysics (al-hikma), but implies that teleology can be seen as its sum and substance. ${ }^{69}$

What is more, if final causation were restricted to intentional acts, Avicenna would face a second problem: that of unrealized ends. In intentional acts a final cause need not come into concrete existence for its effect to come into concrete existence. Let us say, for example, that unbeknown to me my son has drunk the bottle of soda in the refrigerator. My motion to the refrigerator will come into concrete existence even if the bottle of soda is not there, that is, despite the fact that my quenching will fail to come into concrete existence. In Mubāhata 5 Avicenna seems to be grappling with this problem:

If it [the existence of the effect] were to issue as a result of the thingness of something else whose existence is conceived, it [what was conceived] would be a cause whether or not it existed [in the outside world]; yet a thing's existence will not be causally dependent upon that whose non-existence and whose existence is all the same to it. As long as the cause of existence does not exist, its effect will not exist. Were something to exist regardless of whether some other thing existed or not, [the latter] would have no effect in its existence other than straightforward simultaneity [al-ma'iyya al-sādiğa]; but causality is more than simultaneity, even though it goes hand in hand with simultaneity. ${ }^{70}$

${ }^{68}$ Metaph. 1.2, 982b5-11. At least this is how Alexander of Aphrodisias understood the above passage: in Metaph. 1.2 (CAG I), 14,3-4; cp. in Metaph. 1.3 (CAG I) (ad 983a31-33), 22,7-13; in Metaph. 3.2 (CAG I), 184,21-4; in Metaph. 5.2 (CAG I), $346,14 \mathrm{ff}$. and $350,28-32$.

${ }^{69}$ Ilāhiyyāt, 300,7-9. Despite Avicenna's bald assertion of the primacy of teleology, most scholarly interest in Avicenna's theory of causality has focused almost entirely on the efficient cause; see E. Gilson's two articles, "Avicenne et la notion de cause efficiente," Atti del XII Congresso Internazionale di Filosofia (Florence, 1960), 12130, and "Notes pour l'histoire de la cause efficiente," AHDLMA, 29 (1962): 7-31; and M. Marmura's two articles, "The metaphysics of efficient causality in Avicenna," in M. Marmura (ed.), Islamic Theology and Philosophy (Albany, 1984), 172-87, and "Avicenna on causal priority," in P. Morewedge (ed.), Islamic Philosophy and Mysticism (Delmar, N.Y., 1981), 65-83 (esp. 65-72).

${ }^{70}$ Al-Mubāhațāt, ed. M. Bīdārfar (Qom, 1992), 116,15-117,2 (= Mubāhatata 5, \#277); compare 93,5-8 (= Mubāhatata 4, \#177). Concern about how the final cause's possible 
In other words, if it makes no difference whether or not the final cause exists concretely for its effect to exist concretely, the final cause will not fulfill the basic criterion of causality: being that whose existence necessitates the effect's existence. At best the final cause will be a cause only metaphorically.

Now Avicenna is clear that mental existence fully warrants being called existence. So he could defend himself by saying that even in the case of unrealized ends the final cause did exist and its existence did necessitate the effect's existence; the final cause simply existed in the mind, not in concrete reality. Nevertheless, the fact remains that in $\mathrm{Mu}^{\text {'tazilite ontology the }}$ ša' which is in the mind alone qualifies as a $m a ' d \bar{u} m$, and not as a mawğüd. Avicenna's use of šay'iyya in Ilāhiyyāt 6.5 to describe how the final cause operates could therefore be interpreted as implying that an unrealized end - that is, a final cause which only ever "exists" in the mind - was a šay' ma 'düm. And given that only a mawğ $\bar{u} d$, not a šay' ma'd $\bar{u} m$, can be properly spoken of as a cause, the final cause would be seen as not satisfying the basic criterion of causality.

Avicenna seems aware of this problem in the Naǧăt/Ilāhiyyāt 1.11 passage on final and efficient causes. There he asserts that "an object [al-ma' $n \bar{a}]$ has an existence in concrete reality and an existence in the soul as well as something common [to both]: what is common [to both] is thingness." Avicenna is implying that for thingness to serve as the basis on which the final cause's priority rests, we will need to add the condition that the end must be realized concretely. Only then will thingness link the object's existence in the mind with its concrete existence in the outside world. Things which have a mental existence but no corresponding concrete existence - unrealized ends, that is will not be much use in pointing to the final cause's priority.

It is my view that Avicenna moved from šay'iyya in Ilāhiyyāt 6.5 and Nağàt/Ilāhiyyāt 1.11 to māhiyya in the Išàrāt precisely to skirt these various problems. Avicenna starts using šay'iyya in order to pre-empt one Aristotelian problem - the possibility of circularity in the relation between efficient and final causes and then later discards šay'iyya in favor of mähiyya because using šay'iyya created the two further problems just discussed, each of which undermined the primacy of the final cause.

non-existence affects its causality is also evident in Awhad al-Zamān Abū al-Barakāt al-Bag̉dādī, Kitāb al-mu'tabar fì al-ḥikma III (Haydarabad, 1938-39), 52,12-53,5. 
Avicenna's chronological progression from šay'iyya to māhiyya can be detected in his discussions of efficient and final causality, for his assertions about the basis on which the final cause's priority rests change from šay'iyya and haqiqqa in the Ilāhiyyāt and the Nağàt (middle period), to haqiqqa and māhiyya in the Išàrāt (late period). ${ }^{71}$ This becomes even clearer when we look carefully at the progression of Avicenna's thought within the middle period. According to Gutas' careful reconstruction, Avicenna started writing the Kitāb al-šifā' with Tabi 'iyyāt 1 (i.e., al-Samā $\left.a l-t a b \bar{\imath}^{(} \bar{\imath}\right)$ but stopped after finishing only twenty folios; then wrote Manțiq 1 (i.e., al-Madhal); then completed Tabì 'iyyāt 1; and then wrote the entire Ilāhiyy $\bar{a} t .{ }^{72}$ After completing the rest of the Kitāb al-šif $\bar{a}$ ' Avicenna wrote the Năgăt.

The fact that Avicenna had already written the Madhal but had not yet started the Ilähiyyāt is clear from his discussion of the relationship between efficient and final causality in Țabì iyyāt 1:

The agent is, in a way, a cause of the end; how could it not be so, when the agent is what makes the end occur as an existent? The end is, in a way, the cause of the agent; how could it not be so, when the agent acts only on account of it [the end]; otherwise, why would it be acting? For the end sets the agent in motion towards being an agent... The agent is not a cause of the end's becoming an end, nor of the end's essence (māhiyya) in itself; rather it is a cause of the existence of the end's essence in concrete reality. The difference between essence and existence is as you already know. The end is a cause of the agent's being an agent, for it [the end, reading fa-hiya] is the cause of [the agent's] being a cause, whereas the agent is not a cause of the end in terms of [the end's] being a cause. This will be made clear in First Philosophy. ${ }^{73}$

Having taken into account all the new evidence from Parts 2 and 3, I can make the following additions (in bold) to my earlier

${ }^{71}$ Michot (J. Michot, "La réponse d'Avicenne à Bahmanyār et al-Kirmānī," Le Muséon, 110/1-2 [1997], 143-221) has recently argued for an earlier dating of the Išārāt, based on evidence contained in Mubāhată 3. Given our current uncertainty about the Mubāhatâat - in particular, if they constitute a single work from a single period or are, as it seems to me, a grab-bag of many separate discussions recorded over Avicenna's lifetime - I feel Michot's conclusion remains highly tentative, and the traditional late dating of the Išărāt should be retained. Avicenna does use the term šay'iyya once in the Mantị of the Išārāt (Kitāb al-išārāt wa al-tanbihāat, 15,6-8; šay'iyya appears on line 8) but in the context of describing the function of the specific difference (al-faşl), not in the context of final and efficient causality.

${ }^{72}$ Gutas, Avicenna and the Aristotelian Tradition, 101-12. Compare al-Ǧūzğānī's prologue to the Sifá ' in Mantiq (1), 2,13-3,17 and his description of the composition of the Sifá' contained in his biography of Avicenna (Gohlman, Life, 54,1-60,7).

${ }^{73}$ Al-Samá 'al-țabì 'ì min kitāb al-šif à', ed. J. Āl Yāsīn (Beirut, 1996), 114,3-11. 
chart of the progression in Avicenna's thought about thingness and essence:

1) Madhal 1.2: The essences of things (māhiyyāt al-ašyā') are sometimes found in concrete objects in the outside world, and other times are conceived of in the mind. But essence has three aspects: as a concrete, external existent; as a mental, internal existent; and a third aspect, in which it is unrelated to either concrete or mental existence.

2) Madhal 1.12: Genera and species may be divided into those which are before a state of multiplicity (that is, those contained in the active intellect and the other celestial intellects), those which are in a state of multiplicity (that is, those contained individually in sublunary concrete existents), and those which are after a state of multiplicity (that is, those contained as abstracted universals in human intellects). Taken in itself a genus or a species is a thing. "Animal," taken in itself, is an object ( $m a$ 'nan), regardless of whether it is a concrete or a mental existent, or whether it is general or specific (wa-laysa fi nafsihi bi-'āmmin wa-lā hāasșin).

2.5) Tabī iyyāt 1.11: The efficient cause causes the final cause to exist in concrete reality, that is, to exist in an absolute or affirmative sense; the final cause causes the efficient cause to exist as an efficient cause, that is, to exist in a special sense.

3) Ilāhiyyāt 1.5: "Thing" and "existent" are primary, indefinable categories. Whatever is predicable of thing will also be predicable of existent, and whatever is predicable of existent will also be predicable of thing. Although they are co-implied, thing and existent have different meanings.

4) Ilāhiyyāt 5.1: A universal (kullī) such as "horseness," taken in and of itself ( $f i$ nafsihi) - that is, without considering whether it is one or many (la wāhid wa-lā kațīr), a concrete existent in the outside world or a mental existent inside the soul (lā mawğūd fì al-a'yān wa-lā mawğùd fì al-nafs), in potentiality or in actuality (lā bi-al-quwwa wa-lā bi-al-fi $\left.{ }^{\prime} l\right)$ - is a thing (šay').

4.5) Ilāhiyyāt 6.5: The other causes are prior to the final cause in terms of existence; the final cause is prior to the other causes in terms of thingness. The other causes are the causes of the final cause's existence; the final cause is the cause of the other causes' thingness. Thing is logically prior to existent ("the difference between thing and existent is just like the difference between some entity and its concomitant" - 292,2-3); thingness is operative only when existent in the soul, i.e. in intentional action. 
5) Ilāhiyyāt 7.1: "One" (al-wāhìid) and "existent" (al-mawğūd) are equally predicable of things (qad yatasāwiyāni fi al-haml 'alā al-ašy $\bar{a}$ '); all that may be characterized by "one" may also be characterized by "existent," but the two terms do not have the same meaning as each other.

6) Nağàt/Ilāhiyyāt 1.9: "One" is a necessary accident of things (min al-a'rād al-lāzima li-al-ašyā'). Essence is a thing (bal takūnu al-màhiyya šay'an), be it a man or a horse, an intellect or a soul; that thing is only subsequently characterized as being one or existent.

7) Nağàt/Ilāhiyyāt 1.11: The other causes are prior to the final cause in terms of existence; the final cause is prior to the other causes in terms of thingness; thingness is what is common to both mental existence and concrete existence.

8) Išàrāt/Fì al-wuğūd wa- ilalihi: The final cause is a cause, through its essence, of the causality ('illiyya) of the efficient cause; the efficient cause is a cause of the existence of the final cause.

Avicenna's use of māhiyya when discussing the final cause's priority in the Išàrāt suffered from none of the obstacles strewn across the path of his earlier uses of šay'iyya. Unlike šay'iyya, màhiyya was clearly identified with form, so natural phenomena with forms but no intentionality could more easily be accommodated in a universal teleology. Unlike a šay'iyya in the mind, which smacked of the Mu'tazilites' non-existent thing, the mental existence of a mâhiyya was explicitly allowed for, so unrealized ends with mental but no concrete existence could more easily satisfy the basic criterion of causality. And unlike šay'iyya, māhiyya was clearly held to be logically prior to existence, so the primacy of final causation could be more easily upheld. For all these reasons Avicenna opted for mähiyya, and in so doing went some way to resolving the tension between his inconsistent uses of the term šay', and by extension, between his concepts of thingness and essence.

\section{CONCLUSION}

Any claims of definitiveness would be presumptuous in an article which focuses on two of the most complex and wide-ranging topics in Avicenna's philosophy, essence and causality. This is 
why my article can only be called "Notes." I have marshaled enough evidence merely to justify offering the following hypotheses: that the discussions of things and existents by the mutakallimūn and by Fārābì were the immediate backdrop to Avicenna's distinction between essence and existence; that šay'iyya served to link these discussions and Avicenna's distinction; that despite some indications otherwise Avicenna uses the term šay'iyya to explain how the final cause is prior to the efficient cause; and that Avicenna's incompatible ideas about thingness and essence, in the course of their being applied to the problem of distinguishing final and efficient causality, approach resolution.

But offering hypotheses and proving them are different matters. In Part 1, I would need to examine all available works of the early mutakallimūn to determine whether a tradition of using šay'iyya existed before Māturīdī and Avicenna. It seems to have begun with Māturīdī, but I can claim only to have looked for šay'iyya in what I considered to be the obvious places; perhaps it can be found in less obvious places. In Part 2 I would need to examine all available manuscripts of the Ilāhiyyāt and the Nağa t to be absolutely sure that a mistranscription of šay'iyya for sababiyya did not occur early on in the manuscript traditions of those two works. I feel the balance of evidence which I presented in Part 2 compels us to retain šay'iyya, but the evidence is far from unequivocal, and my conclusion will necessarily be tentative. In Part 3, I would need to be more certain of the chronology of Avicenna's writings - and particularly the dating of the Išărāt - than is possible now. This will require closer analysis of the entire Mubāhațāt and Ta 'lìqāt. My hypothesis that Avicenna's thought progresses from šay'iyya to māhiyya squares more easily with the traditional late dating of the $I \bar{s} \bar{a} r \bar{a} t$ than it does with an earlier dating. That of course is not in itself evidence for the Išārāt's late dating, for my hypothesis is too contingent on other suppositions to qualify as evidence itself.

But several lessons can still be learned from this story. The lesson from Part 1 is that analysis of the texts tells us that despite their frequent use of the oppositional labels "mutakallim" and "faylasūf," and despite our own tendency to see mutakallimūn and falāsifa as naturally opposed categories, Arabic thinkers of the pre-Avicennian period had much in common conceptually as well as terminologically. The lesson from Part 2 is that just as 
Arabists should make a distinction between Aristotle's works in the original Greek and their ninth- and tenth-century Arabic translations, so Latinists must be careful to qualify their claims about Arabic philosophy when they base those claims solely on its Latin versions. Many mistranslations are trivial, but some are crucial. The lesson from Part 3 is that an author as prolific as Avicenna will often defy our attempts to systematize his thought. The corpus of his work is organic and complex, not static and unitary. It contains serious contradictions, and while some may be shown to be irreconcilable, and some may be shown to be superficial, others can be explained as signs of his intellectual development. 